Johanne Ur Scebø

Universitetet i Stavanger

Atle Skaftun

Universitetet i Stavanger

Arne Olav Nygard

Universitetet i Stavanger

DOI: http://doi.org/10.5617/adno.8311

\title{
Vilkår for muntlig deltakelse på mellomtrinnet
}

\begin{abstract}
Sammendrag
I denne artikkelen søker vi å gi svar på følgende spørsmål: Hvilke muntlige dialogiske rom finnes i klasseromshverdagen på mellomtrinnet? Det gjøres ved å studere mulighetene elevene får til å bruke stemmen sin og språket sitt i læringsarbeidet. Studien er basert på observasjoner i fire klasser på mellomtrinnet på én skole. Hver av klassene har blitt observert i én uke. Fyldige feltnotater samt lydopptak i én av klassene utgjør datamaterialet. I analysen identifiseres først hvilke organiseringsformer som er nyttet i alle de observerte timene (helklasse, individuelt arbeid, par- og gruppearbeid). Videre identifiseres og undersøkes den muntlige interaksjonen i helklasseundervisningen, og da spesielt sekvenser med dialogisk potensial. Drøftingen indikerer at elevene på mellomtrinnet, selv i et fellesskap preget av relasjonell anerkjennelse, i liten grad inviteres inn i utforskende dialoger der de får bruke sitt språk og sine idéer i møte med faglige problemstillinger. Med henspill på de siste tiårs nasjonale satsinger rettet mot fornyelse av skolens praksis i retning av mer elevaktive arbeidsformer, er dette tankevekkende. Studiens bidrag er å tilby realistiske bilder fra klasseromshverdagen som utgangspunkt for å peke på vilkår for å skape dialogiske rom der elevene får bruke sitt språk og sine idéer i faglig utforsking.
\end{abstract}

Nøkkelord: dialog, stemme, muntlighet

\section{Conditions for oral participation in upper elementary school}

\begin{abstract}
In this article we seek to answer the following question: Which oral dialogic spaces are to be found in the 5th to 7th grade classrooms? We do this by investigating the students' opportunities to participate orally during classroom activites during one week of observation in four classes from grades 5 to 7 at one school. We made extensive field notes as well as sound recordings in one of the classes. In the analysis we first identify the different forms of organization of the observed lessons (whole class, seat work, pair and group work). We then identify and investigate the oral interaction in whole class, especially the sequences with dialogues and discussions. The analysis indicates that there is little explorative dialogue where the students can use their own language and ideas in encounters with subject-related issues. This is problematic, considering the national efforts of renewing school practices, with particular focus on increasing student participation and activities. The study provides a realistic picture of everyday school
\end{abstract}


activities and points out necessary conditions for the creation of dialogic spaces where the students can use their language and ideas to explore disciplinary content.

Keywords: dialogue, voice, oracy

\section{Innledning}

Norsk skole har de siste tiårene vært gjenstand for et økende endringstrykk, i form av nye læreplaner, nasjonale satsinger rettet mot fornyelse av praksis i skolen og i fagene (Kunnskapsdepartementet, 2016, 2017; Utdanningsdirektoratet, 2019), og de siste årene i en storstilt ordning for desentralisert kompetanseutvikling (Kunnskapsdepartementet, 2017). Samlet representerer disse styringsdokumentene tydelige signaler som peker mot en skole der elevene spiller en langt mer aktiv rolle som lærende deltakere i faglige praksiser, og dermed også en bevegelse mot praksiser slik de er beskrevet og foreskrevet i en lang tradisjon for progressiv utdanningsforskning rettet mot fornyelse av tradisjonell praksis (Dewey, 1938; Barnes \& Shemilt, 1974; Nystrand, 1997; Alexander, 2008; Mercer et al., 2019). Samtidig viser evalueringer av tidligere reformer i Norge og i andre deler av verden at reformer i liten grad endrer strukturen i skolens praksis (Cuban, 2013; Hodgson et al., 2013; Klette, 2003; Lefstein, 2008). I dette spenningsfeltet mellom progressiv retorikk og tradisjonell praksis - eller mellom formulerings- og realiseringsarenaen, som Lindensjö og Lundgren (2000) kaller det - synes det svært fornuftig å arbeide for å forankre store mål i realistiske bilder av klasseromshverdagen.

Med denne artikkelen søker vi å bidra til kunnskap om den muntlige interaksjonen i klasseromshverdagen på mellomtrinnet, med intensjon om å identifisere rom for elevenes stemmer og samtalenes dialogiske potensial. Mellomtrinnet er særlig interessant som et steg mellom en innføring i akademisk kultur og ulike fags literacy i gradvis utvikling mot en mer regulert og summativ vurderingspraksis i ungdomstrinnet. I den grad år 5 - 7 er et trinn mellom noe, er det altså et trinn mellom to ulike skolekulturer; på den ene siden overgangen fra barnehage til de første skoleårenes innføring i akademia, og på den andre siden ungdomstrinnets tydeligere faglige innramming og nye vurderingsformer med et blikk framover i utdanningsløpet. Med en interesse for denne mellomposisjonen i skoleløpet spør vi: Hvilke muntlige dialogiske rom finnes i klasseromshverdagen på mellomtrinnet? 


\section{Muntlighet i forskning og praksis}

Det finnes en solid teoretisk og empirisk forskningsbase som viser at kvaliteten på klasseromssamtalen henger sammen med kvaliteten på elevenes læring, problemløsing og forståelse (jf. Applebee et al., 2003; Mercer, 1995; 2000; Nystrand, 1997; 2006; Wegerif, Mercer \& Dawes, 1999; Murphy et al., 2009). Mer generelt handler det om instruksjonskvalitet som vesentlig faktor for elevenes læringsutbytte, slik det er formulert i LISA-prosjektet (Linking Instruction and Student Achievement), en omfattende studie av klasseromspraksis på ungdomstrinnet i norsk skole (Klette et al., 2017). Dialogisk undervisning bidrar, slik det framholdes av utdanningsforskeren Robin Alexander (2008), til at elevenes forståelse og engasjement utvikles ved at idéer og ulike perspektiver analyseres og utforskes gjennom dialog. Utdanningsforskeren Rupert Wegerif foreslår begrepet dialogiske rom (2013) som en måte å fokusere, gripe og legge til rette for slike møteplasser, der idéer kan flettes sammen, utfordres og utvikles til nye idéer.

Det er imidlertid et kjent fenomen at eksisterende praksiser i skolen er motstandsdyktige mot ambisiøse reformer (Lefstein, 2008). «Tradisjonelle praksiser» (jf. Goodlad, 2004; Cazden, 2001; Hicks, 1995), der lærer er formidler og elevene forventes å reprodusere kjent kunnskap, har godt fotfeste, og nye begreper lar seg som regel innpasse i gamle forståelsesrammer (jf. Barnes \& Shemilt, 1974). Vektleggingen av muntlige ferdigheter i læreplanene fra 2006 er et godt eksempel på denne mekanismen. Frøydis Hertzberg (i Møller et al., 2010) framholder at ferdighetene, og da spesielt de språklige, kan oppfattes som selvsagte. Muntlighet synes dessuten å ha kommet i skyggen av lesing og skriving. Én forklaring kan være at muntlig kommunikasjon er flyktig og kontekstuell, og krevende å vurdere. Dessuten er det å uttrykke seg muntlig en ferdighet barn tar med seg inn i skolen, og det tenkes ikke i like stor grad som en ferdighet man skal lære når man begynner i første klasse. Paradoksalt nok synes overgangen fra barnehage til skolens begynneropplæring å bety en vending fra bevisst og målrettet arbeid med barnets utvikling av muntlig språk, til muntlige praksiser hvor stillhet er assosiert med orden og godt læringsmiljø (Skaftun \& Wagner, 2019). I rapporten Sammenhengen mellom Undervisning og læring (SMUL-rapporten) belyses hele opplæringsløpet, og lærernes praksis under Kunnskapsløftet analyseres. Rapporten viser at det foregår mye muntlig samhandling i norske klasserom (Hodgson et al., 2012). 61\% av undervisningstida blir i gjennomsnitt brukt til helklasseundervisning, og $15 \%$ til gruppearbeid, som begge er organiseringsformer som har potensial for engasjert muntlig interaksjon. Rapporten viser likevel at praksisen i stor grad er preget av manglende dybde, der den muntlige samhandlingen kjennetegnes mer av enkel reproduksjon av kunnskapselementer enn av utforsking og kritisk tenkning (Hodgson et al., 2012, s. 11). Bildet av en klasseromspraksis med stort rom for muntlig aktivitet bekreftes av andre studier (Aukrust 2003; Bergem \& Klette, 2010; Emanuelsson 
\& Sahlström, 2008; Klette \& Ødegaard, 2015), samtidig som det pekes på at elevene oftest engasjeres i praktiske aspekter ved undervisningen, heller enn kognitivt krevende utforsking (Emanuelsson \& Sahlström, 2008; Klette \& Ødegaard, 2015).

Den danske utdanningsforskeren og dramapedagogen Mads Haugsted skiller mellom det han kaller muntlighet i undervisningen og undervisning i muntlighet (Haugsted, 1999). Dette begrepsparet er et nokså elegant uttrykk for den sammenhengen Haugsted etterlyser, mellom på den ene siden den muntlige interaksjonen man har i skolehverdagen som ressurs i det pedagogiske arbeidet, og en bevisst pedagogisk bearbeiding av denne ressursen. SMUL-rapporten og andre nordiske studier av klasseromsinteraksjon (Hodgson et al., 2012; Danelund \& Kruchov, 1979; Gustafsson, 1977; Klette, 2003; Klette et al., 2017; Klette \& Ødegaard, 2015; Andersson-Bakken, 2015) føyer seg inn i en interesse for den sosiale organiseringen av klasseromssamtalen eller -diskursen, og bekrefter bildet av en stabil praksis hvor læreren snakker mest og elevens ytringer i stor grad er respons på spørsmål som læreren allerede vet svaret på. I kjølvannet av Kunnskapsløftet (2006) har vi sett en tendens til å vende fokus mer mot ferdighetsaspektet av muntlighet, og dermed i større grad mot eksplisitt undervisning i muntlighet. Noen forskere fokuserer på talesjangre, diskursstrategier og opplæring i muntlige ferdigheter (Svenkerud et al., 2012; Matre \& Fottland, 2011; Svenkerud, 2013), i tråd med læreplanens fokus på utvikling av språkkompetanse. I deler av denne forskningen er oppmerksomheten spesifikt rettet mot forberedte presentasjoner (Svenkerud et al, 2012; Svenkerud, 2013), som har fått stor plass i skolens vurderingspraksis. Det måles mye, men det blir i liten grad undervist i det som måles - en situasjon som kan minne om Durkins (1978) epokegjørende påvisning av misforholdet mellom undervisning i og testing av leseforståelse.

Det er mye som taler for at muntlig interaksjon i norske klasserom fortjener oppmerksomhet som en ressurs med stort potensial for å realisere de mange og store ideene i fagfornyelsen (Utdanningsdirektoratet, 2019). På veien inn i denne typen utviklingsarbeid synes det fornuftig å tegne realistiske bilder av eksisterende praksis. Slike aktuelle bilder av praksis som fokuserer på vilkår for muntlig deltakelse, kan være et viktig bindeledd mellom innsikten i «the persistence of recitation» (Hoetker \& Ahlbrandt, 1969) som er bekreftet mange ganger, og profesjonsutvikling med realistiske ambisjoner.

\section{Teoretisk forståelsesramme}

Denne studien er forankret i en sosiokulturell forståelse av språk og læring. Ifølge den russiske psykologen Lev Vygotskij oppstår barnets tenkning i møte med andre, der språket som intellektuell ressurs brukes for å forstå omverdenen, skape mening og utvikle identitet (Vygotskij, 1986). Implikasjonene av denne 
sammenhengen mellom tenkning og språk leder fram mot å legge til rette for dialog i læringsarbeidet. Den russiske litteraturviteren og filosofen Mikhail Bakhtins dialogbaserte språkteori (Bakhtin, 1981, 1986) supplerer Vygotskijs utviklingsspsykologiske teori ved at den løfter fram dialogen i arbeidet med å utvikle mening og kunnskap (Alexander, 2008; Wertsch, 1991; Wegerif, 2016). Deltakerne bringer med sine ytringer inn stemmer fra ulike posisjoner slik at kunnskap reaksentueres og nyskapes ved at man kontinuerlig stiller spørsmål til den. Mening og forståelse overføres altså ikke, men oppstår som et samarbeid mellom deltakerne og de stemmene som bringes inn i dialogen. Dialogen består da ikke bare av de stemmene som faktisk er å høre i klasserommet (Smidt, 2004), men også av klangen av andre og tidligere stemmer - både det som er sagt før i verden, og det den enkelte har med seg inn i samtalen som reflekterer kulturell og sosial påvirkning (Bakhtin, 1981). I denne flerstemmigheten er elevene myndige aktører, og det gis muligheter for at ny innsikt kan vokse fram ved at etablerte idéer kan granskes gjennom kritisk refleksjon i et mangfoldig fellesskap. I slike klasserom posisjoneres elevene som aktive lærende. Deres bidrag blir da tatt på alvor, stilt spørsmål ved og bygget videre på - ikke i form av ukritisk opphøying av individet, der enhver ytring er eksklusiv på grunn av sin autentisitet (Arnot \& Reay, 2007), og heller ikke som en romantisk tanke om å lokke fram den enkeltes innerste personlige stemme (Smidt, 2004). Det er derimot tale om en undersøkende praksis der elevene bruker språket i felles utforsking, og der de blir stilt til ansvar for sine ytringer ${ }^{1}$.

Praksis brukes ofte for å betegne noe man gjør, altså konkrete handlinger. Når vi leser om god pedagogisk praksis i ny overordnet del av læreplanen, så er det nærliggende å knytte dette til lærerens valg, handlinger og tilrettelegging. Når vi møter formuleringen «skolens praksis», er det rimelig å utvide perspektivet og støtte seg til en forståelse av praksis som en sosial struktur som legger føringer for hvem som gjør hva, når, hvor og hvordan. Begge disse perspektivene på praksis er i spill blant lærere og utdanningsforskere, og det er ofte klokt å klargjøre hva man mener med praksis på et tidlig tidspunkt hvis man ønsker en meningsfull diskusjon om fornyelse av praksis.

\footnotetext{
${ }^{1}$ I det flerstemmige, dialogiske klasserommet er det lærende fellesskapet sentralt. Man kan likevel ikke direkte trekke en slutning om at tilrettelegging for dialog i fellesskapet vil føre til en friksjonsfri tilslutning og deltakelse fra enhver elevs side. Den enkelte elevs evne til og ønske om å engasjere seg i dialogen kommer til uttrykk i elevens selvposisjonering, et begrep som Hetmar (2019, s. 220-221) setter i forbindelse med Davies agency (1990), altså elevens mulighet til å handle som myndig. I dialogens intersubjektive prosess foregår det dessuten en aktiv kultivering av selvet (Böhm, 1997). Dette «selvets eget arbeid» (1997, s. 199) gir også rom for å si «nei», å protestere eller å vende seg bort fra situasjonen (Biesta, i Sævi \& Biesta, 2020).
} 
Det finnes mange teorier om sosial praksis, men fire elementer utgjør noen uomgjengelige kjerneelementer (jf. f.eks. Ivanic, 2009 og van Leeuwen, 2008), og kan illustreres som et samspill av faktorer som alle bidrar til å forme og opprettholde den sosiale strukturen som utgjør en praksis. En endring i ett av elementene vil kunne påvirke de andre elementene, og praksisen som helhet formes av samspillet mellom elementene (se fig. 1 ). ${ }^{2}$ Pilene i modellen er ment å illustrere den gjensidige sammenhengen mellom elementene. Denne strukturen

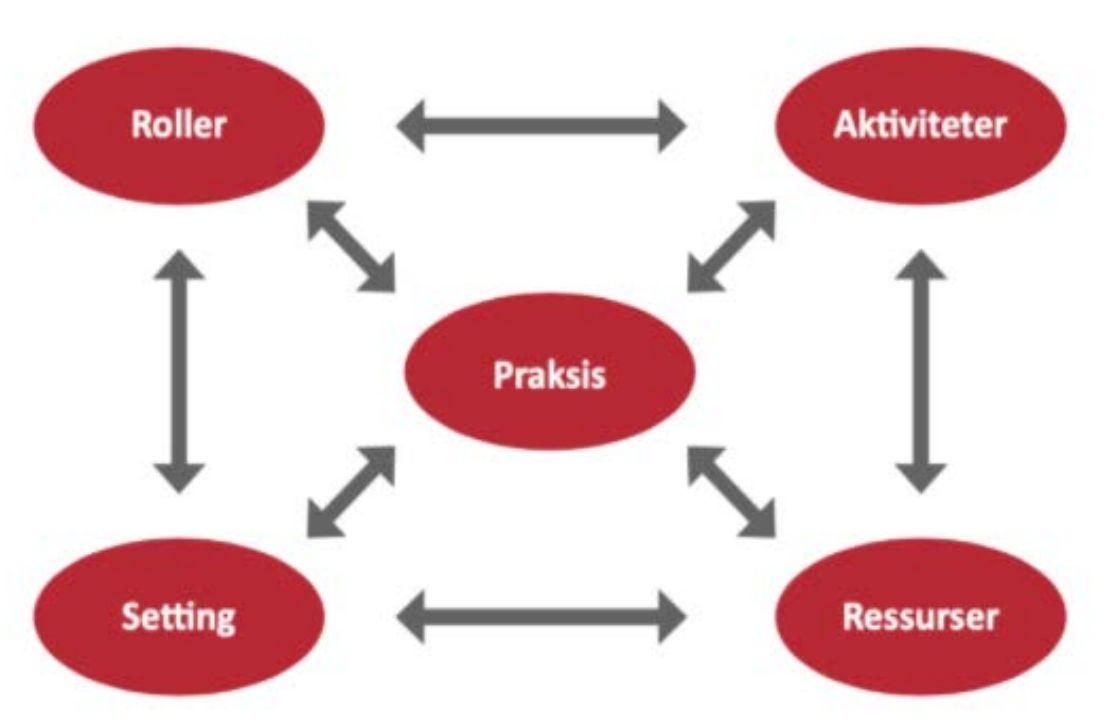

som holder elever og lærere på plass i tradisjonelle roller har vist seg svært motstandsdyktig mot skolereformer og pedagogiske strømninger. ${ }^{3}$

I tradisjonelle

Figur 1: Illustrasjon av samspillet mellom sentrale aspekter ved sosial praksis.

undervisningspraksiser ligger det til elevens rolle å reprodusere og gjengi kunnskap, som er produsert i det Bernstein (2001) kaller produksjonsfeltet. ${ }^{4}$ Kunnskapen ses i slike praksiser på som statisk og absolutt (Kuhn, 1991), og læreren er autoriteten som innehar, formidler og kontrollerer denne kunnskapen. Lærerrollen tillegges med andre ord mye makt, noe som også viser seg i de muntlige aktivitetene, der læreren stiller spørsmål for å sjekke om elevene har tatt til seg den kunnskapen som læreren har formidlet. Med et sosiokulturelt læringssyn arbeides det i tråd med progressive idealer mot en praksis der kunnskap og mening utvikles gjennom stadig pågående utforsking i fellesskapet, med den følge at distribusjonen av makt mellom lærer- og elevrollen kan

\footnotetext{
${ }^{2}$ Modellen er utviklet i et partnerskap for desentralisert kompetanseutvikling mellom UiS og Jærskolen (jf. Skaftun, 2020). Innenfor denne rammen refereres det til modellen som «Praksismodellen».

${ }^{3}$ Bellack med kolleger (1966) beskrev klasseromsinteraksjon med støtte i Wittgensteins språkspillteori. Hoetker og Ahlbrandt (1969) fulgte opp Bellacks studie med referanser tilbake til slutten av 1800-tallet, og presiserte at et passende navn på språkspillet i klasserommet var og er resitasjon. Tittelen på studien fra 1969 - «the persistence of recitation» - er svært talende for hva progressive og dialogiske perspektiver har kjempet mot $\mathrm{i}$ forsøkene på å fornye skolens praksiser, og da særlig elevrollen.

${ }^{4}$ Bernstein (2000; 2001) har gjennom sin 'pedagogiske anordning' ('Pedagogic Device') gitt kriterier for eksplisitte regler for å beskrive kunnskapens makro- og mikrostrukturer og særlig de generative relasjonene mellom makt og kontroll som konstituerer kunnskapen i skolen og feltene som hører til det pedagogiske apparatet (produksjonsfeltet, rekontekstualiseringsfeltet og reproduksjonsfeltet) (Bernstein, 2001).
} 
balanseres. I en felles meningskonstruksjon kan det gis muligheter for lærerelev-relasjoner basert på «power with» i stedet for «power over» eleven (Gipps, 1999, s. 380). Dialog og dialogisk undervisning innebærer da kvaliteter som symmetri mellom partene, vilje til å lytte og være åpen - kvaliteter som er tiltalende å slutte seg til (Dysthe, 2006, s. 13). At man har et ideal om å fremme dialogiske kvaliteter, garanterer likevel ikke for at idealet gjennomsyrer praksis.

Utdanningsforskerne Aliza Segal og Adam Lefstein har utviklet en modell for realisering av elevens stemme (2016), på bakgrunn av at de i sin forskning har sett at den faglige samtalen i klasserommet oftest blir overflatisk, på tross av at elevene tilbys mye taletid, og selv om læreren har intensjoner om at elevene skal få uttrykke seg gjennom kumulativ dialog. De karakteriserer den observerte klasseromsdialogen som rituell, og begrunner det med at elevene i stor grad forsøker å ta etter lærerens stemme og prøver å speile det faglige innholdet og lærerens vokabular, som de oppfatter som det verdsatte (2016, s. 2). Segal og Lefsteins modell holder fram fire vilkår for at elevens stemme skal kunne realiseres: Eleven må (a) gis mulighet til å uttrykke seg, (b) få uttrykke egne tanker og idéer, (c) få uttrykke seg med egne ord og (d) få anerkjennelse for sine utsagn. Disse fire vilkårene er strukturerende for artikkelens drøfting av vilkår for elevers muntlige deltakelse på mellomtrinnet.

\section{Metode}

\section{Utvalg og Sørvestskolen som case}

I perioden 2017-2019 deltok vi på samlinger for skolebasert kompetanseutvikling på «Sørvestskolen». Lærerne på mellomtrinnet ville arbeide med muntlighet som tema, og vi kom inn i dette arbeidet som interesserte partnere. Samlingene hadde fokus på erfaringsdeling og refleksjon omkring ulike forståelser av muntlighet. Den viktigste betydningen disse møtene hadde for denne studien, var etablering av en tillitsfull relasjon og tilgang til klasserommene deres. Feltarbeidet ble gjennomført høsten 2018, og omfattet i utgangspunktet alle de fem klassene på skolens mellomtrinn. I klasse 7B la læreren om undervisningen, og gjennomførte litterære samtaler i seks av de ni observerte timene, trolig ut fra en oppfatning av at det var dette vi ville observere. Observasjonene i 7B representerer en interessant case i seg selv, men med utgangspunkt i vår ambisjon om å gripe og beskrive hverdagen på mellomtrinnet, har vi valgt å holde observasjonene i denne klassen utenfor materialet for denne artikkelen.

Sørvestskolen er en relativt liten skole, der det på mellomtrinnet er fem klasser i alt; to klasser på 5. trinn, én på 6. trinn og to på 7. trinn. Den ene 7. klassen (angitt i parentes i tabell 1 under) er i det videre utelatt fra materialet, ut fra den tidligere nevnte begrunnelsen. 
Tabell 1: Oversikt antall lærere og elever i de fem klassene

\begin{tabular}{|l|l|l|l|l|l|}
\hline Klasse & $5 \mathrm{~A}$ & $5 \mathrm{~B}$ & 6 & $7 \mathrm{~A}$ & $(7 \mathrm{~B})$ \\
\hline Antall kontaktlærere & 1 & 1 & 2 & 1 & $(1)$ \\
\hline Antall elever & 18 & 18 & 27 & 17 & $(20)$ \\
\hline
\end{tabular}

\section{Metoder for datainnsamling}

Studien er etnografisk inspirert både gjennom perspektivtaken og bruken av etnografiske verktøy (Green \& Bloome, 1997), og da særlig i form av observasjon og deltakelse i feltet over tid. I og med at det var et poeng å få et realistisk bilde av klasseromshverdagen, la vi forskere vekt på at observasjonen i klasserommet skulle være så lite inngripende som mulig. Sammen med lærerne ble vi enige om at kun én forsker skulle være til stede i undervisningen. Hun plasserte seg bak i de aktuelle klasserommene, slik at hun observerte undervisningen fra elevperspektiv, og hennes og lærernes erfaring var at elevene ikke lot seg påvirke i særlig grad av forskerens tilstedeværelse. Feltarbeidet innebar én ukes observasjon i hver av klassene. Observasjonen omfattet tre timer hver dag (med unntak av én dag med to timer), begrunnet ut fra en antakelse om at man ikke får vesentlig ny informasjon ved å øke antall observerte timer pr dag (Howe et al., 2019). De observerte timene favner om ulike fag, noe som gir et rikt og helhetlig bilde av klasseromshverdagen.

Vi forskere utarbeidet et skjema ${ }^{5}$ for observasjon (se vedlegg 1 ) i forkant av feltarbeidet, ut fra en interesse for å kunne gi en fyldig beskrivelse av klasseromshverdagen, og samtidig kunne identifisere organiseringsformer og gi et bilde av klasseromsinteraksjonen. Skjemaet var ment å støtte observasjonsarbeidet. Tabellformatet ble valgt for å fange aktivitetsskifter og ikke minst synliggjøre tidsflyten gjennom timen som helhet. Innenfor disse tidsrammene ga skjemaet rom for enkel avkryssing knyttet til fenomener vi på forhånd så som meningsfulle å identifisere og som potensielle kategorier i kodingsarbeidet. Ved at feltnotatet gav rom for en narrativ beskrivelse, i tillegg til notering av tidskoder og avkryssing for organiseringsformer og læringsaktiviteter, var det mulig å identifisere og skille mellom hendelser i undervisningen, samt å kunne estimere varigheten av hendelser i hendelsene. Observasjonen var både rettet inn mot både lærerens og elevenes aktiviteter, med intensjon om å kunne fange opp samhandlingen i undervisningen. Den narrative framstillingen av undervisningstimen var i første rekke deskriptiv, men skjemaet ga i en parallell kolonne plass for tanker og tolkninger underveis. Hver dags notater og inntrykk ble dessuten samlet og bearbeidet ved en begynnende analyse $\mathrm{i}$ et oppsummeringsskjema. Det ble også tatt lydopptak fra timene i 7A, der alle elevene og foreldrene ga samtykke til dette. Opptakene ble gjort ved hjelp av én

\footnotetext{
${ }^{5}$ Vi tok utgangspunkt i og bearbeidet et observasjonsskjema som var blitt prøvd ut av to av forskerne i et lignende forskningsprosjekt, med beslektet formål.
} 
mikrofon som var plassert framme i klasserommet. Samtalene på opptakene ble videre transkribert i sin helhet.

\section{Analysemetoder}

I arbeidet med å analysere datamaterialet identifiserte vi først hvordan undervisningen var organisert i alle de observerte timene (helklasse, individuelt arbeid, par- og gruppearbeid), og hvordan det prosentvis fordelte seg, både i hver klasse og totalt. Videre identifiserte og undersøkte vi den muntlige interaksjonen i helklasseundervisningen, og hvilke samtaleformer som var i bruk. Til slutt undersøkte og kodet vi sekvensene med dialogisk potensial - hvem som tok initiativ til disse, sekvensens varighet og grad av faglighet. Kodingsarbeidet ble gjort ved hjelp av Nvivo.

Kategoriene for organiseringsformer var datadrevne på den måten at det var disse formene for organisering som framkom i undervisningen. I Helklasseundervisning inngikk all undervisning der oppmerksomheten var rettet mot læreren og klassen som helhet. Kategoriene Arbeid i par og Gruppearbeid viser til læringsarbeid gjennomført i par eller i grupper på tre elever eller mer. Individuelt arbeid var sekvenser der elevene jobbet selvstendig én og én. Kategorien Annet ble lagt til for å fange opp aktiviteter som dreide seg om administrasjon og logistikk, slik som inn- og utgang, rydding, forflytning og lignende. I tillegg er det en kategori for hendelser som tydelig ikke var undervisning, slik som pauser elevene hadde utenom de faste friminuttene (Ikke undervisning). Koding av hendelsene i feltnotatene i NVivo synliggjorde forekomster av de ulike organiseringsformene. Selve fordelingen av tid på de ulike organiseringsformene ble gjort manuelt, og tallmaterialet som kom ut av dette arbeidet ble bearbeidet og systematisert i Excel, noe som ga en detaljert oversikt som videre ble brukt for å sammenholde informasjon ytterligere.

I andre del av analysen undersøkte og kodet vi samtaleformene innen helklasseundervisningen ${ }^{6}$. I helklasseundervisnings samtaler er det potensielt rom for at elevene skal få bruke stemmen sin, idéene og språket sitt for å lære i fellesskapet. Hvor mye plass elevenes stemmer får, avhenger blant annet av hvor mye plass lærerens stemme tar. Kategoriene som ble brukt i kodingen av helklasseundervisningen avspeiler dette kontinuumet ved at det beskriver grader av elev- og lærerdominans i samtalen. De fem kategoriene er utarbeidet av Skaftun og Wagner (2019), med utgangspunkt i Robin Alexanders beskrivelse av talk in everyday life, talk for teaching og talk for learning (Alexander, 2008, s. 38-39):

1) Erfaringsdeling og fortelling (elevdominans)

2) Samtaler med dialogisk potensial (lærer og elever)

\footnotetext{
${ }^{6}$ Det forekom også samtaler innen par- og gruppearbeid, men av praktiske grunner var det ikke mulig å fange dem opp. Studiens fokus på helklasseundervisningens samtaler understøttes av at forekomsten av par- og gruppearbeid var relativt lav.
} 
3) Dialogisk instruksjon (instruksjon med involvering av elever (IRE $\left.{ }^{7}\right)$ )

4) Formalisert tale (høytlesing, sang o.l.)

5) Instruksjon uten elevinnspill (lærerdominans)

Erfaringsdeling og fortelling (1) beskriver sekvenser der elevene fritt forteller eller deler sine erfaringer, uten å bli vesentlig regulert av lærer eller andre. Ytringer av denne typen representerer et bindeledd mellom elevens og skolens diskurs, og kan synliggjøre forkunnskaper og erfaringer i møte med faglige emner. I andre enden av skalaen finner vi Instruksjon uten elevinnspill (5) som innebærer lærers monolog. Formalisert tale (4) utgjør for eksempel høytlesing og sang, altså sekvenser der elevstemmen brukes til å gjengi et gitt innhold. Kategorien dialogisk instruksjon (3) omfatter den ovenfornevnte IRE-samtalen, der samtalen reguleres av lærer, og elevene er bidragsytere i lærers resonnement. Kategori 2) ble brukt for å fange opp samtalesekvenser med dialogisk potensial. Kategorien ble i første omgang brukt inklusivt, med tanke på videre nærlesing og sortering. Kategori 2) innebar altså ikke primært en direkte identifisering av dialogiske kvaliteter, men var snarere et ledd i datareduksjon.

De to første stegene i analysen avspeiler en bevegelse fra en deskriptiv til en stadig mer fortolkende tilnærming som bidro til datareduksjon og innkretsing av samtalesekvenser med dialogisk potensial (kategori 2 i listen ovenfor). Disse sekvensene (altså kategori 2) er i fokus i analysens tredje og siste del. Basert på nærlesing ble alle samtalesekvensene i kategori 2 kodet for varighet (kort - lang), initiativ (lærer eller elev), og faglighet (faglig - ikke-faglig). De korte sekvensene (>1 minutt) ble skilt ut fra de øvrige. Skillet ved ett minutt ble satt fordi kategorien korte sekvenser viste seg å være stor; 33 av de 58 sekvensene var på ett minutt eller mindre. Videre ble sekvensene med dialogisk potensial som nevnt kodet ut fra om de var initiert av lærer eller av elever. Kategoriene faglig og ikke-faglig innebærer større grad av fortolkning enn de foregående. Faglige samtaler forstås her som samtaler som er rettet inn mot å utvikle kunnskap i det aktuelle faget slik det kommer til uttrykk i læreplanmålene, mens ikke-faglige samtaler oftest omhandler rent praktiske og relasjonelle aspekter.

Organiseringsformer og samtaleformer er langt på vei deskriptive kategorier som bidrar til datareduksjon. Kategoriene dialogisk potensial og faglighet krever tolkning i større grad. Disse tolkningene er gjort i forskergruppa som tolkningsfellesskap, hvor vi arbeidet fram konsensus. De tre analysestegene muliggjør en identifisering og undersøkelse av de muntlige dialogiske rommene som finnes i klasseromshverdagen på mellomtrinnet, med ambisjon om å tilby kunnskap om realiseringen av elevens stemme i møte med faglige problemstillinger.

${ }^{7}$ IRE-samtalen; Lærer initierer, respons fra elev(er), evaluering av responsen (Mehan, 1979) 


\section{Analyse}

Analysen faller i tre deler. Den første delen tegner et bilde av hvordan undervisningen er organisert i løpet av observasjonsperioden. Den andre delen beskriver distribusjonen av samtaleformer i samme periode, med særlig fokus på helklasseundervisning som det markant mest sentrale rommet for interaksjon i de observerte klasserommene. I den tredje delen av analysen undersøkes én av samtaleformene, samtaler med dialogisk potensial, mer inngående.

\section{Organiseringsformer $\mathrm{i}$ undervisningen}

I alt 38 skoletimer på 45 minutter ble observert, fordelt på fire klasser på mellomtrinnet. En oversikt over observerte timer fordelt på klasser, og hvordan de ulike organiseringsformene fordeler seg, gis i tabell 2 .

Tabell 2: Oversikt observerte timer og fordeling av organiseringsformer

\begin{tabular}{|l|c|c|c|c|c|c|c|c|}
\hline & $\begin{array}{c}\text { Observer } \\
\text { te timer }\end{array}$ & $\begin{array}{c}\text { Minutter } \\
\text { observert }\end{array}$ & $\begin{array}{c}\text { Helklasse } \\
- \\
\text { undervisn } \\
\text { ing }\end{array}$ & $\begin{array}{c}\text { Individu } \\
\text { elt } \\
\text { arbeid }\end{array}$ & Pararbeid & $\begin{array}{c}\text { Gruppe- } \\
\text { arbeid }\end{array}$ & $\begin{array}{c}\text { Annet } \\
\text { under- } \\
\text { visning }\end{array}$ \\
\hline 5 A & 6 & 270 & $37 \%$ & $53 \%$ & & & $8 \%$ & $2 \%$ \\
\hline $5 \mathrm{~B}$ & 9 & 405 & $29 \%$ & $57 \%$ & $3 \%$ & & $9 \%$ & $2 \%$ \\
\hline $6 . \mathrm{tr}$ & 11 & 495 & $44 \%$ & $37 \%$ & $7 \%$ & $1 \%$ & $9 \%$ & $1 \%$ \\
\hline $7 \mathrm{~A}$ & 12 & 540 & $36 \%$ & $39 \%$ & $6 \%$ & & $11 \%$ & $9 \%$ \\
\hline $\begin{array}{l}\text { Sum } \\
\text { / snitt }\end{array}$ & 38 & 1710 & $37 \%$ & $45 \%$ & $5 \%$ & $0,4 \%$ & $9 \%$ & $4 \%$ \\
\hline
\end{tabular}

Undervisningen på mellomtrinnet på Sørvestskolen domineres av helklasseundervisning og individuelt arbeid, selv om det fordeler seg noe ulikt i de ulike klassene. I begge de to klassene på femte trinn er det vesentlig mer individuelt arbeid enn helklasseundervisning. Noe av grunnen til dette er at fire av de femten observerte timene var kunst og håndverk, der elevene jobba individuelt hele timene. På 6. trinn dominerer helklasseundervisning, mens det $\mathrm{i}$ 7A er en liten overvekt av individuelt arbeid. I alle klasser er det to til fire timer der individuelt arbeid utgjør to tredeler av tiden eller mer, noe som antyder at lærerne legger opp til noen mer eller mindre rene arbeidstimer. Det er sju hendelser med pararbeid fordelt på tre klasser, noe som i gjennomsnitt utgjør $5 \%$ av den totale undervisningen på mellomtrinnet. Som tabellen viser, utgjør gruppearbeid 0,4 \% av alle de observerte timene, og nærmere bestemt én hendelse på 7 minutter på 6. trinn. Andelen Annet er mellom 8 og $11 \%$ i alle klasser. At rundt 5 minutter av hver undervisningstime går med til rydding og inn- og utgang oppleves som rimelig. Hyppige skifter i undervisningen vil nødvendigvis påvirke tallet i og med at det tar tid å for eksempel hente nye bøker, og ved at oppmerksomheten skal rettes mot noe nytt. Sekvenser kodet som Ikke undervisning er pauser/friminutt som ble gitt i løpet av dobbelttimer, sein oppstart av timer, samt en 15-minutters fellessamling for hele skolen i løpet av uka i 7A. 


\section{Samtaleformer i helklasseundervisningen}

Helklasseundervisning som organiseringsform tilbyr muligheter for utforskning av faglige problemstillinger i klassefellesskapet, og da med språket som viktig redskap. Ulike samtaleformer vil innebære ulikt potensial for interaksjon og variasjon i elevdeltakelse. Når intensjonen er å få øye på sekvenser der elevene tilbys muligheter til å bruke stemmen, idéene sine og språket for å lære, vil det være interessant å i neste omgang undersøke forekomst av de ulike samtaleformene i helklasseundervisningen. Distribusjon av de fem samtaleformene framkommer i tabell 3.

Tabell 3: Distribusjon av samtaleformer innen helklasseundervisning i de fire klassene

\begin{tabular}{|l|c|c|c|c|c|}
\hline & $5 \mathrm{~A}$ & $5 \mathrm{~B}$ & 6. tr & $7 \mathrm{~A}$ & Gj.snitt \\
\hline Erfaringsdeling og fortelling (1) & $2 \%$ & $4 \%$ & $7 \%$ & $5 \%$ & $5 \%$ \\
\hline $\begin{array}{l}\text { Samtaler med dialogisk potensial } \\
(2)\end{array}$ & $19 \%$ & $13 \%$ & $14 \%$ & $21 \%$ & $17 \%$ \\
\hline Dialogisk instruksjon (3) & $16 \%$ & $31 \%$ & $31 \%$ & $21 \%$ & $25 \%$ \\
\hline Formalisert tale (4) & $7 \%$ & $5 \%$ & $4 \%$ & $4 \%$ & $5 \%$ \\
\hline Instruksjon uten elevinnspill (5) & $56 \%$ & $47 \%$ & $44 \%$ & $49 \%$ & $48 \%$ \\
\hline
\end{tabular}

Helhetsbildet av den muntlige aktiviteten på Sørvestskolen viser at instruksjon uten elevinnspill dominerer ved å utgjøre $48 \%$ av helklasseundervisningen. Videre består helklasseundervisningen av 25 \% dialogisk instruksjon, altså samtaler som er tydelig regulert av lærer ved at elevene tildeles rollen å respondere på lærers initiativ. Formalisert tale utgjør $5 \%$ av undervisningstiden i helklasse. Denne kategorien innebærer som nevnt sang eller høytlesing. $5 \%$ av helklasseundervisningen brukes til at elevene får dele sine erfaringer og fortellinger. Samtaler med dialogisk potensial utgjør $17 \%$ av undervisningen i helklasse.

Lærerstyrte samtaleformer - instruksjon uten elevinnspill (48 \%) og dialogisk instruksjon (25 \%) - er altså dominerende i helklasseundervisningen. Instruksjon uten elevinnspill kan dreie seg om sekvenser der lærer legger opp til gjennomgang av prosedyrer, eksempelvis skriver på tavla, og snakker gjennom og modellerer regneoperasjoner. Det kan også dreie seg om at lærer foreleser eller forteller enten ved å greie ut om faglige emner eller ved å fortelle mer personlige historier med løsere tilknytning til faget. Instruksjon innebærer også regulering av atferd og informasjon om arbeidsoppgaver og hva som skal skje. I noen tilfeller kommer elever med innspill i læreres monolog. Slike sekvenser er likevel kodet som instruksjon ut fra at lærer ikke legger opp til elevinnspill, og heller ikke svarer på eller bygger videre på elevens initiativ i vesentlig grad.

Samtaler som reguleres av lærer, men der elevene inviteres som bidragsytere i lærers resonnement (dialogisk instruksjon), opptar en fjerdedel av helklasseundervisningen. Samtalene spenner fra lærers spørsmål med gitte, korte svar, som «Hva er en boomerang?» og «Hvem har skrevet diktet?», til spørsmål som åpner opp for fyldigere svar, slik som hva forfatteren av en tekst har ment, 
eller hva det vil si å være saklig. En del av samtalene innledes med spørsmål om prosedyre, slik som «Hva må vi gjøre?» i forbindelse med felles gjennomgang av regneoperasjoner. Lærerne kan med sine spørsmål ha til hensikt å oppklare eller repetere oppgaver, men spørsmålene kan også ha oppsummerende og klargjørende effekt, ved at lærer spør «Hva har vi trent på med disse oppgavene?». Noen av de mest åpne samtalene kan synes å trekke i retning av dialog eller diskusjon, men selv om spørsmålene kan synes åpne, synliggjør lærers respons at hans/hennes resonnement er styrende for hvilken retning samtalen kan ta.

Formalisert tale (5\% av helklasseundervisningen) er i utgangspunktet en regulert form, og sekvensene med sang og høytlesing er i tillegg planlagt av og styrt av lærer. Vedkommende leser enten selv, eller tildeler oppgaven til elever enten ved «rekkelesing» eller ved at elever pekes ut eller melder seg til å lese høyt i klassen.

Sekvensene med erfaringsdeling og fortelling $(5 \%$ av helklasseundervisningen) dreier seg oftest om hverdagsfortellinger som springer ut av det faglige temaet, men som ikke bidrar vesentlig til å bygge fellesskapets faglige forståelse.

Samtalesekvenser som kan sies å inneha dialogisk potensial utgjør nær en seksdel av helklasseundervisningen, og gjøres rede for i det videre.

\section{Samtaler med dialogisk potensial}

Samtalesekvenser som gir noe større rom for elevenes selvstendige innspill enn det som er typisk for IRE-samtalen, er kodet som samtaler med dialogisk potensial (2). Hvordan denne typen samtale fordeler seg i de ulike klassene vises i tabell 3:

Tabell 4: Distribusjon av samtaler med dialogisk potensial i de fire klassene

\begin{tabular}{|l|c|c|c|c|c|c|}
\hline & $\begin{array}{c}\text { Observert } \\
\text { undervisning, } \\
\text { min }\end{array}$ & $\begin{array}{c}\text { Helklasse- } \\
\text { undervisning, } \\
\text { min }\end{array}$ & $\begin{array}{c}\text { Helklasse- } \\
\text { undervisning, } \\
\text { prosent }\end{array}$ & $\begin{array}{c}\text { Samtaler } \\
\text { med } \\
\text { dialogisk } \\
\text { potensial, } \\
\text { min, av } \\
\text { total tid }\end{array}$ & $\begin{array}{c}\text { Samtaler med } \\
\text { dialogisk } \\
\text { potensial, \% } \\
\text { av helklasse- } \\
\text { undervisning }\end{array}$ & $\begin{array}{c}\text { Samtaler med } \\
\text { dialogisk } \\
\text { potensial, \%, } \\
\text { av total tid }\end{array}$ \\
\hline 5A & 270 & 100 & $37 \%$ & 19 & $19 \%$ & $7 \%$ \\
\hline 5B & 405 & 117 & $29 \%$ & 15 & $13 \%$ & $4 \%$ \\
\hline 6. tr & 495 & 220 & $44 \%$ & 31 & $14 \%$ & $6 \%$ \\
\hline 7A & 540 & 194 & $36 \%$ & 41 & $21 \%$ & $8 \%$ \\
\hline $\begin{array}{l}\text { Sum/ } \\
\text { snitt }\end{array}$ & 1710 & 631 & $37 \%$ & 106 & $17 \%$ & $6 \%$ \\
\hline
\end{tabular}

Sekvensene med dialogisk potensial utgjør i gjennomsnitt $17 \quad \%$ av helklasseundervisningen, og i underkant av $6 \%$ av all undervisning. Sekvensene i denne kategorien er kodet ut fra at elevene gis taletid og rom til selvstendige ytringer i samspill med hverandre og lærer. Potensialet for dialog forstås som tilløp til utforsking i et jevnbyrdig fellesskap, og kan for eksempel ha form av åpne og/eller utforskende spørsmål, en dialogisk holdning fra lærers side eller 
utvekslinger der elevene bygger på hverandres utsagn. I materialet framkommer det i alt 58 sekvenser med dialogisk potensial (se vedlegg 2). Disse er igjen kodet ut fra varighet, hvorvidt det er lærer eller elever som tar initiativ til samtalen, og om sekvensene kan sies å være faglige ved at de sikter mot å utvikle kunnskap i det aktuelle faget slik det kommer til uttrykk i læreplanmålene. Sekvensenes varighet sier noe om samtalens kumulative kvaliteter (Alexander, 2008), og hvilke rom som gis for oppfølging og utvikling av tankerekker. En identifisering av hvem som tar initiativ til samtaler med dialogisk potensial tilbyr informasjon om elevengasjement og om lærernes bevissthet om hva dialog kan tilføre undervisningen. Hvorvidt sekvensene med dialogisk potensial kan sies å være faglige eller ikke, forteller noe om dialogiske kvaliteter anses å være produktive i møte med faglige problemstillinger, eller om de nyttes i større grad i møte med praktiske utfordringer og for å styrke det relasjonelle i klassemiljøet.

Ut fra dette analysesteget ser vi at hovedvekten av sekvensene (33 av 58) er ett minutt eller kortere, at det er like mange elevinitierte sekvenser som lærerinitierte (29) og at samtalene i 42 av de 58 sekvensene er direkte eller indirekte rettet inn mot faglige mål. Tabell 5 viser hvordan de 58 sekvensene med dialogisk potensial fordeler seg med tanke på varighet, initiativ og faglighet.

Tabell 5: Sekvenser med dialogisk potensial: varighet, faglighet og initiativ.

\begin{tabular}{|l|c|c|c|c|}
\hline & \multicolumn{2}{|c|}{ Kort $(<1 \mathrm{~min})$} & \multicolumn{2}{c|}{ Lang $(>1 \mathrm{~min})$} \\
\hline & Faglig & Ikke-faglig & Faglig & Ikke-faglig \\
\hline Lærerinitiert & 9 & 4 & 15 & 1 \\
\hline Elevinitiert & 10 & 10 & 8 & 1 \\
\hline
\end{tabular}

Sekvensene fordeler seg ulikt på fag (se vedlegg 2). I fagene norsk og samfunnsfag finner vi til sammen 42 sekvenser med dialogisk potensial, mens det i engelsk, KRLE, kunst og håndverk og matematikk er tre til fire i hvert fag. Det er interessant, både med tanke på læreplanmålene og et økende fokus på elevaktiv og utforskende matematikk, at det er få potensielt dialogiske sekvenser i matematikktimene (4). Disse er dessuten enten av ikke-faglig art eller relativt innholdsløse, som at lærer åpner for spørsmål etter gjennomgang av en prosedyre, uten at det fører videre. I engelsk er det tre sekvenser, der lærer i den ene spør elevene etter emner til en quiz, mens de to andre sekvensene er ikke-faglige. De fire korte sekvensene i kunst og håndverk/formingsaktiviteter dreier seg om faglige praktiske utfordringer som løses raskt med korte utvekslinger.

Den ene av de fire samtalesekvensene i KRLE fortjener oppmerksomhet fordi den oppstår som den eneste i en time preget av monologisk undervisning, og ut fra en elevs initiativ. I denne timens undervisning om hinduismen er det lærers og lærebokas stemme som dominerer i det som er gjennomgang av faktafokuserte spørsmål og svar fra læreboka. Midt i dette dukker en elevs tanker om gudsbegrepet opp, og han stiller et spørsmål med utgangspunkt i et autentisk dilemma: «Alle kan ikke være gud, alle sammen?» (feltnotat og transkr. 181120). På den måten bringer han i spill forståelser både fra religion som fagfelt og som 
utøvende praksis. Som innledning til sitt spørsmål skaper han et resonnement basert på det han muligens tenker at ligner lærers faglige framstilling:
$\left(197^{8}\right)$ Elev:
(198) Lærer:
Ehm ... Vi lærer om gudene i den [hinduismen], ja ${ }^{9}$ ?
(199) Elev:
(200) Lærer:
Ja.
(201) Elev:
(202) Lærer:
Ja, om India. Også vi har lært om kristendom?
Ja.
Ehm ... Jeg har ... Og i verden mange som tror på mye.
Mhm.
(203) Elev:
(...) Alle kan ikke være gud, alle sammen?

Læreren gir ham noe tid, og aksepterer resonnementet hans, men unnviker utforskingen av elevens egentlige spørsmål ved å respondere slik: «Ja, nei, vi forstår det ikke fordi vi forstår ikke helt hvorfor» (218). Dette var et kritisk øyeblikk, med potensial for å engasjere elevene til utforskende dialog med utgangspunkt i et seriøst og ikke minst autentisk spørsmål. Potensialet blir imidlertid ikke utløst. Lærer runder av, og undervisningen går videre i form av faktafokusert instruksjon.

De fleste samtalesekvensene med dialogisk potensial finner vi i norsk- og samfunnsfagtimene (henholdsvis 30 sekvenser fordelt på ti timer, og 12 sekvenser fordelt på to timer). Dersom vi ser på de 19 faglige sekvensene i norsktimene, er det lærer som initierer langt de fleste. Sekvensene oppstår oftest fra lærers åpne spørsmål om læreboktekster. En tendens er at elevsvarene «lukker» samtalen, og at lærer virker å se seg fornøyd med det. Et eksempel på dette er når lærer spør om elevene kan si noe om diktet de har lest, og elevene responderer med å liste opp kjennetegn på dikt. Det antyder at lærer har et ideal om å stille åpne spørsmål, men likevel verdsetter elevenes gjengivelse av kunnskapselementer høyere.

Elevinitiativene er få i norsktimene, men én av disse sekvensene er interessant fordi den viser selvstendige og kritiske elevstemmer, der elever bringer inn nye elementer og begreper i sammenheng med tolkningen av Roald Dahls versjon av eventyret om Rødhette. I diskusjonen om teksten utbryter en elev om Rødhette at «hun er jo ond!», og en annen elev bringer selvforsvar inn som et relevant begrep i forsøket på å forstå Rødhettes handlinger. Nok en elev stiller spørsmål ved det at noen tillater seg å skyte. Lærer sammenholder selvforsvar-begrepet med et antatt utspill fra Donald Trump om at lærere bør være bevæpna, og dramatiserer hva som da kan skje dersom man ikke har gjort leksene. En tredje elev responderer med «Jeg tror ikke det er det han mener» (feltnotat 181211). Elevene inntar her en aktiv posisjon i arbeidet med å skape mening og relevans i tekstarbeidet, og viser seg myndige i vurderingen av relevansen i lærers anekdote.

Alle de 12 sekvensene i samfunnsfag er fra to sammenhengende timer der lærers uttalte mål er at de sammen skal utfordre lærebokas framstilling av Christoffer Columbus. Tematisk byr undervisningen på utforsking og dialog, også

\footnotetext{
${ }^{8}$ Tallene i parentes viser til nummerering av ytringene i transkripsjonen.

${ }^{9}$ Eleven har begrensede norskspråklige ferdigheter.
} 
ved at den setter i spill autentiske tekster. Lærer spør flere ganger underveis: «Hvilket bilde har dere av Christoffer nå?» (feltnotat og transkr. 181122), og inviterer også til vurdering av kildene som er i bruk. Elevene initierer over halvparten av samtalesekvensene, noe som indikerer engasjement. Eksempelvis spør en elev om Columbus hadde slaver, og en annen elev protesterer på at noen kan «ta land» når det allerede bor noen der. Nesten alle elevinitiativene fra disse timene er korte. Selv om de har potensial til utforskende dialog, gis ikke denne dialogen næring fordi lærer, i stedet for å løfte elevinnspillene inn i fellesskapet, svarer på elevenes spørsmål i en instruerende form.

Sammenfattende kan vi si at fagenes egenart og tematikk ser ut til å virke inn på i hvor stor grad man finner samtaler med dialogisk potensial, slik som litterære samtaler eller refleksjon over ulike kilders informasjon. Denne logikken brytes likevel ved at det er så få dialogiske sekvenser i matematikk og KRLE, der utforsking, samtale og refleksjon er tenke- og handlemåter som er uttrykt i læreplanmålene (Utdanningsdirektoratet, 2013; 2015). Det synes videre å være en tendens at det er utfordrende for lærer å bruke elevinitiativ videre i en felles utforsking i klassen, muligens fordi det innebærer en viss uforutsigbarhet. Mange av de lærerinitierte samtalene innledes med et åpent spørsmål, noe som indikerer at lærerne anser denne typen spørsmål som positive. At svært få av disse samtalesekvensene strekker seg over mer enn tre minutter tyder likevel på at de åpne spørsmålene ikke stimulerer til en videre utforskende dialog. I noen tilfeller kan dette skyldes at det som etterspørres først og fremst er preferanser (hvilken tekst elevene likte best eller hva de synes om skolefrukt) uten at lærer ber om videre utdypning. Noen av spørsmålene er dessuten svært åpne, jf. eksempelet der lærer spør om elevene kan si noe om diktet de har lest. Spørsmålet angir ingen tydelig retning, noe som kan oppleves som uhåndterbart for elevene. At elevene da svarer med å gjengi fakta, antyder at de spiller det spillet de tror læreren spiller, nemlig at lærers spørsmål krever et svar som skal framvise innlært kunnskap.

\section{Drøfting}

I det følgende drøftes den muntlige klasseromsinteraksjonen i de fire mellomtrinnsklassene med henblikk på hvilke muntlige dialogiske rom som finnes der. De fire nivåene for realisering av elevens stemme i Segal og Lefsteins modell (2016) er strukturerende for drøftingen: mulighet for å uttrykke seg; få uttrykke egne tanker og idéer; få uttrykke seg med egne ord; og få anerkjennelse for sine utsagn.

For i det hele å komme i posisjon til å bruke språket og idéene sine $\mathrm{i}$ læringsarbeidet, må elevene få taletid og muligheter for å uttrykke seg. Læreren kan regulere elevens «access to the floor» (Segal \& Lefstein, 2016, s. 3) gjennom valg av organiserings- og samtaleform. Selv om lærerne ved Sørvestskolen uttrykker at de ønsker at elevene skal være muntlig aktive («Nå handler det om å 
gjøre dem trygge nok til å komme på banen, og si sin mening», memo 181120), og at de foretrekker litt «liv og røre» («Det er en fin, travel gjeng», feltnotat 5B181206), begrenses dette i virkeligheten av at undervisningen domineres av individuelt arbeid (45\% av all undervisning, jf. $21 \%$ i SMUL-rapporten). Videre preges helklasseundervisningen av lærers instruksjon $(48 \%$ av helklasseundervisningen), noe som gir lite rom for elevenes stemmer. Praksisen kan assosieres med tradisjonell undervisning, der stabil kunnskap overføres fra den som vet (læreren) til den som ikke vet (eleven) (Säljö, 2001), hvor eleven posisjoneres som passiv konsument, framfor at kunnskap utvikles i en pågående prosess der man sammen undersøker ulike perspektiver og idéer. Ønsket om et levende klasserom kan være uttrykk for et ideal om læreren som den som stimulerer til aktivitet og som verdsetter konstruktiv uro og engasjement. Idealet kan likevel vise seg vanskelig å leve opp til dersom man ubevisst henter rollemodeller fra egne erfaringer som elev, og ubevisst legger seg tett opptil en tradisjonell rolleforståelse (Skaftun et al., 2017). At instruksjon er en kjent og foretrukket undervisningsform uttrykkes faktisk også ved ett tilfelle eksplisitt ved at en lærer forteller elevene at hun, da hun gikk på skolen, likte godt når læreren snakket og skrev på tavla, og at elevene bare kunne høre og skrive av (feltnotat 181211).

Segal og Lefsteins vilkår om at eleven må få uttrykke egne tanker og idéer (2016) henspiller på det å gi rom for elevens uttrykk for selvstendig tenkning og eksperimentering med og utforsking av forståelser. Elevens spørsmål i eksempelet fra KRLE-timen er nettopp et kraftfullt uttrykk for hans egen selvstendige idé. Spørsmålet er en ansats til dialog som inviterer til å bevege undervisningen inn mot utforsking av fenomener. Lærer er sensitiv (jf. Lefstein \& Snell, 2014) for at eleven har noe på hjertet som han selv synes er presserende, og hun gir ham noe rom til å legge dette fram, men i og med at hun ikke tar innover seg hvilke forståelser eleven snakker ut fra, holder på rollen som autoritet og samtidig tilsynelatende mangler repertoar (jf. Lefstein \& Snell, 2014) for å vurdere mulige responser, blir det umulig å utvikle elevenes innspill til en reell dialog i fellesskapet. Da glipper også muligheten til å utforske dyptgripende fenomener som er faglig relevante. I stedet går undervisningen om hinduismen videre i form av instruksjon med gjengivelse av kunnskapselementer, og elevens erfaring blir at det er lærers faglige sti som skal følges. Lærerens fastholdelse av egen rolle som autoritet minsker altså elevens mulighet til å prøve ut en initierende, aktiv og utforskende rolle.

I den norskfaglige samtalen som dreier seg om Roald Dahls versjon av eventyret om Rødhette skaper elevene et felles resonnement i tolkningen av eventyret, bringer inn nye begreper og etterstreber faglig relevans. Eksempelet fra KRLE-timen viser en tilsvarende innsirkling mot sentrale faglige elementer. Elevene i begge eksemplene bruker begreper som både er faglig relevante og som har utspring i deres egne forståelser. De uttrykker seg med egne ord (Segal \& Lefstein, 2016), og initierer samtaler som potensielt kan åpne for en utforskende 
dialog. Lærerne på sin side benytter i liten grad mulighetene som elevinnspillene gir. Tvert om synes det som om de styres mer av egne referanser eller av egen plan for timen, og da utgjør disse elevinnspillene en forstyrrelse. Elevenes initiativ begrenses, og dermed også deres rom til å engasjere seg i og utforske faglige problemer. Når elevenes anvendte fagspråk ikke videreutvikles, inviteres de heller ikke videre inn i den akademiske diskursen. Ved at lærer iscenesetter og fastholder kun trygge og enkle samtalesituasjoner, benyttes ikke det motivasjons- og læringspotensialet som ligger i de mer risikable meningssøkende og utprøvende samtalene. Det at elevenes initiativ til å ta tak i faglige problemstillinger lukkes ned av lærer, er et markant uttrykk for lærerrollens innflytelse på mulighetene elevene får til kognitivt krevende utforsking, noe som også etterlyses i tidligere studier (Klette \& Ødegaard, 2015; Emanuelsson \& Sahlström, 2008).

Ett av mange dilemma lærere må forholde seg til i faglige samtaler er å gi rom for og verdsette elevenes selvstendige stemmer samtidig med at samtalen er faglig fokusert, koherent og undersøkende (Segal \& Lefstein, 2016). Resultatene i den tidligere nevnte SMUL-rapporten (Hodgson et al., 2012) er et uttrykk for at dette kan være utfordrende. Det at elevene får anerkjennelse for sine utsagn i fellesskapet anses som avgjørende for utvikling av dialogiske kvaliteter (Segal \& Lefstein, 2016). Dette beror selvsagt på lærerens relasjonelle kompetanse, og hvorvidt elevene opplever seg som inkluderte og satt pris på. Elevene på Sørvestskolen har lærere som viser interesse for den enkelte, og som legger til rette for et godt klassemiljø. Helhetsinntrykket under observasjonen er at lærerne er imøtekommende og varme, og at de snakker fint til og godt om elevene sine. Dette inntrykket samstemmer med andre studier fra norske klasserom (Hodgson et al., 2012; Klette, 2003; Danelund \& Kruchov, 1979; Gustafsson, 1977; Skaftun \& Wagner, 2019). I disse klassefellesskapene er elevenes ytringer i utgangspunktet ønsket. En følge av dette ønsket er at det først og fremst er det å ytre seg som verdsettes. Elevene oppfordres til å snakke, og det er noe rom for deres hverdagsfortellinger og erfaringer. Slike samtaler gir først og fremst næring til det sosiale og relasjonelle, noe som selvsagt har verdi, og som kan sies å underbygge et anerkjennende fellesskap. Likevel; dersom elevrollen begrenses til å være en sosial og relasjonell rolle, der eleven først og fremst er mottaker av lærers oppmerksomhet og omsorg, vil det fortrinnsvis understreke skolens hierarki, framfor å tilby eleven mulighet til å utvikle rollen som myndiggjort lærende subjekt (jf. Skaftun \& Wagner, 2019). Dersom elevene skal kunne delta i et gjensidig fellesskap der de utforsker faglige problemstillinger sammen, forutsettes det at de av lærer posisjoneres som jevnbyrdige i det faglige språk- og tankefellesskapet som klassen kan være. 


\section{Begrensninger}

I denne studien er søkelyset satt på klasseromshverdagens rom for elevenes språklige utforsking av faglige problemstillinger og medvirkning til utvikling av kunnskap. En begrensning i studien er at den omfatter én skole, og at vi dermed står i fare for å si mer om én skoles kultur enn å gi et rikt bilde av mellomtrinnsundervisning som sådan. Antallet observerte timer er moderat (37). Til sammenligning er antallet observerte timer på mellomtrinnet i SMULrapporten 42. Ved å konsentrere studien til fire sammenhengende uker, vil vi ikke kunne fange opp eventuelle endringer i løpet av skoleåret. Samtidig er skoledagen og -uken forstått og nyttet som meningsfulle enheter som gir informasjon om helheten i undervisningen og om gjennomgående forståelser og handlemåter.

Feltnotater utgjør hoveddataene, og dekker alle de observerte timene. Vi har kun lydopptak (og derav også transkripsjoner) fra én av de fire klassene. Med det begrenses også muligheten til å diskursivt analysere ytringer. I de tre klassene der kun feltnotat er benyttet, er en del ytringer notert ned, og da særlig lærernes. Hele samtalesekvenser lot seg ikke notere eksakt. Derimot er samtalenes kontekst beskrevet fyldig.

\section{Implikasjoner for praksis}

Studien bekrefter et bilde av at tradisjonell undervisningspraksis dominerer norske klasserom (Hodgson et al., 2012; Klette, 2003). Lærerne i de klasserommene som er beskrevet har hatt muntlighet som satsingsområde i et partnerskap med forskere fra Lesesenteret over et helt år før observasjonsperioden, noe som kan forstås som en påminnelse om hvor lang vei det er fra formuleringsarenaen til realiseringsarenaen (Lindensjö \& Lundgren, 2000); fra å snakke om endring av praksis til å gjøre faktiske endringer i strukturer og handlingsrom som er så robuste som tradisjonell skolepraksis og den diskursive organiseringen av klasserommet (Cazden, 2001; Goodlad, 2004; Segal \& Lefstein, 2016). I de store nasjonale satsingene rettet mot skoleutvikling ${ }^{10}$, vil det være nødvendig å anerkjenne at endring av praksis (eksempelvis gjennom partnerskap mellom skole- og UH-sektoren (Kunnskapsdepartementet, 2017)) handler om langsiktig og møysommelig arbeid med underliggende forståelse av samspillet mellom roller, aktiviteter, settinger og ressurser som samlet konstituerer praksis. De store idéene som har drevet fram fornyelse av læreplaner på veien mot framtidens skole peker alle innover mot fornyelse av dette samspillet. Den muntlige interaksjonen i helklasseundervisning er kanskje det tydeligste uttrykket for underliggende praksisforståelse, og dermed også

\footnotetext{
${ }^{10}$ Gi rom for lesing (Utdanningsdirektoratet, 2007), Ny Giv (Kunnskapsdepartementet, 2013), FYR (NOU, 2008:18), Ungdomstrinn i utvikling (Utdanningsdirektoratet, 2012), Språkløyper (Utdanningsdirektoratet, 2016)
} 
meningsfullt å rette blikket mot i arbeidet med praksisfornyelse. Sensitivitet for og verdsetting av pedagogiske øyeblikk med ansatser til dialog vil være et verdifullt første steg i dette arbeidet.

\section{Om forfatterne}

Johanne Ur Sæbø er førsteamanuensis i utdanningsvitenskap ved Lesesenteret, UiS. Hennes forskningsinteresser omfatter muntlighet i undervisningen og utvikling av skolens praksiser gjennom partnerskap.

Institusjonstilknytning: Lesesenteret, Universitetet i Stavanger, 4036 Stavanger.

E-post: johanne.u.sebo@uis.no

Atle Skaftun har doktorgrad i nordisk litteraturvitenskap og er professor i lesevitenskap ved Lesesenteret, UiS. Hans forskningsinteresser omfatter leseopplæring, fagspesifikk literacy, litterære samtaler, og i økende grad deltakelsesstrukturer i skolens og fagenes praksiser. Muntlig interaksjon er en fellesnevner for mange av disse interessene.

Institusjonstilknytning: Lesesenteret, Universitetet i Stavanger, 4036 Stavanger

E-post: atle.skaftun@uis.no

Arne Olav Nygard er førsteamanuensis i lesevitenskap ved Lesesenteret, Universitetet i Stavanger. Han har skrive ei rekke artiklar om literacy og tekstkultur i digitale medium. I den seinare tida har han vore knytt til forskingsprosjekt som handlar om munnlegheit i skulekvardagen.

Institusjonstilknytning: Lesesenteret, Universitetet i Stavanger, 4036 Stavanger E-post: arne.o.nygard@uis.no

\section{Referanser}

Alexander, R. J. (2008). Towards dialogic teaching: Rethinking classroom talk (4. utg.). Dialogos.

Andersson-Bakken, E. (2015). Når åpne spørsmål ikke er åpne: Hva karakteriserer lærerspørsmål i en litterær samtale? Nordic Studies in Education, 34 (03-04). https://www-idunn-no.ezproxy.uis.no/np/2015/0304/naar_aapne_spoersmaal_ikke_er_aapne_-_hva_karakteriserer_laerers

Applebee, A. N., Langer, J. A., Nystrand, M., \& Gamoran, A. (2003). Discussion-based approaches to developing understanding: Classroom instruction and student performance in middle and high school English. American Educational Research Journal, 40(3), 685730. http://dx.doi.org/10.3102/00028312040003685

Arnot, M. \& Reay, D. (2007). A Sociology of Pedagogic Voice: Power, inequality and pupil consultation. Discourse: studies in the cultural politics of education, 28(3), 311-325. https://www.tandfonline.com/doi/full/10.1080/01596300701458814 
Aukrust, V. G. (2003). Samtaledeltakelse i norske klasserom - En studie av deltakerstrukturer og samtalebevegelser. I K. Klette (Red.), Klasserommets praksisformer etter Reform97. Unipib Publishing.

Bakhtin, M. M. (1981). The dialogic imagination: Four essays. (M. Holquist \& C. Emerson, Overs.). University of Texas Press.

Bakhtin, M. M. (1986). Speech genres and other late essays. (C. Emerson \& M. Holquist, Red.). University of Texas Press.

Barnes, D. \& Shemilt, D. (1974). Transmission and interpretation. Educational Review, 26(3), 213-228.

Bellack, A. A., Kliebard, H., Hyman, R. \& Smith, F. L. (1966). The language of the classroom. Teachers College Press.

Bergem, O. K., \& Klette, K. (2010). Mathematical tasks as catalysts for student talk: Analysing discourse in a Norwegian mathematics classroom. I Y. Shimizu, B. Kaur, R. Huang, \& D. Clark (Red.), Mathematical tasks in classrooms around the world (s. 35-62). Sense Publishers.

Bernstein, B. (2001). From pedagogies to knowledges. I A. Morais, I. Neves, B. Davies \& H. Daniels (Red.), Toward a Sociology of Pedagogy. The contribution of Basil Bernstein to research (s. 363-368). Peter Lang.

Bernstein, B. (2000). Pedagogy, Symbolic Control and Identity (Revidert utg.). Rowman \& Littlefield Publishers.

Böhm, W. (1997). Entwürfe zu einer Pädagogik der Person. Julius Klinkhardt.

Cazden, C. B. (2001). Classroom discourse: The language of teaching and learning (2. utg.). Heinemann.

Cuban, L. (2013). Why so many structural changes in schools and so little reform in teaching practice? Journal of Educational Administration, 51(2), 109-125. https://doi.org/10.1108/09578231311304661

Danelund, J. \& Kruchov, C. (Red.). (1979). Projekt skolesprog: Skoledag 1. GMT.

Davies, B. (1990). Agency as a Form of Discursive Practice. A Classroom Scene Observed. British Journal of Sociology of Education, 11(3), 341.

Dewey, J. (1938). Experience and education. Kappa Delta Pi/Touchstone.

Durkin, D. (1978). What classroom observations reveal about reading comprehension instruction. Reading research quarterly, 14(4), 481-533.

https://www.ideals.illinois.edu/bitstream/handle/2142/17858/ctrstreadtechrepv01978i0010 $\underline{6}$ opt.pdf?sequence $=1$

Dysthe, O. (Red.). (2006). Dialog, samspel og laring. Abstract Forlag.

Emanuelsson, J. \& Sahlström. F. (2008). The price of participation. Teacher control versus student participation in classroom interaction. Scandinavian Journal of Educational Research, 52(2), 205-223. https://www.tandfonline.com/doi/full/10.1080/00313830801915853

Gipps, C. (1999). Socio-Cultural Aspects of Assessment. Review of Research in Education 24, 355-392. https://journals.sagepub.com/doi/pdf/10.3102/0091732X024001355

Goodlad, J. (2004). A Place Called School: Twentieth Anniversary Edition (2. utg.). McGrawHill Education.

Green, J. L. \& Bloome, D. (1997). Ethnography and Ethnographers of and in Education: A Situated Practice. I J. Flood, S. B. Heath \& D. Lapp (Red.), Handbook of Research on Teaching Literacy Through the Communicative and Visual Arts (s. 181-202). Macmillan Publishers.

Gustafsson, C. (1977). Classroom interaction: A study of pedagogical roles in the teaching process. Stockholm Institute of Education, Department of Educational Research. 
Haugsted, M. Th. (1999). Handlende mundtlighed: Mundtlig metode og cestetiske læreprocesser. Danmarks lærerhøjskole.

Hicks, D. (1995). Discourse, Learning, and Teaching. Review of Research in Education, 21(1), 49-95. https://doi.org/10.3102/0091732X021001049

Hetmar, V. (2019). Fagpæedagogik i et kulturformperspektiv. Aarhus Universitetsforlag.

Hodgson, J., Rønning, W., \& Tomlinson, P. (2012). Sammenhengen mellom undervisning og læring. En studie av læereres praksis og deres tenkning under Kunnskapsløftet.

Sluttrapport, 4. (No. NF-rapport nr. 4/2012). Nordlandsforskning.

Hoetker og Ahlbrandt (1969). The Persistence of the Recitation. A Rewiew of Observational Studies of Teacher Questioning Behavior. American Educational Research Journal, 6(2), 145-167.

https://journals.sagepub.com/doi/abs/10.3102/00028312006002145?casa_token=N3OQ8 N81TkAAAAA:24MuRSZcqYf3wc_Sh9p_ARepEieIkGI1A_RMJ1uXil8sEnMUIjqBSH PnJYSRJhEjfQeqrTWbuqq

Howe, C., Hennessy, S., Mercer, N., Vrikki, M. \& Wheatley, L. (2019). Teacher-Student

Dialogue During Classroom Teaching: Does It Really Impact on Student Outcomes?

Journal of the Learning Sciences, 28(4-5), 462-512.

https://www.tandfonline.com/doi/full/10.1080/10508406.2019.1573730

Ivanic, R. (2009). Bringing Literacy Studies into Research on Learning Across the

Curriculum. I M. Baynham \& M. Prinsloo (Red.), The future of literacy studies (s. 100122). Palgrave Macmillan.

Klette, K. (2003). Evaluering av Reform 97. Klasserommets praksisformer etter Reform 97. Universitetet i Oslo. Norges Forskningsråd. https://www.duo.uio.no/bitstream/handle/10852/32308/Reform97_Rapp_1_03_web.pdf?s equence $=1$

Klette, K. \& Ødegaard, M. (2015). Instructional activities and discourse features in science classrooms: Teachers talking and students listening or ...? I K. Klette, O. K. Bergem, \&

A. Roe (Red.), Teaching and learning in lower secondary schools in the Era of PISA and TIMMS (s. 17-31). Springer.

Klette, K., Blikstad-Balas, M. \& Roe, A. (2017). Linking Instruction and Student Achievement - Research design for a new generation of classroom studies. Acta Didactica Norge, 11(3).

https://www.duo.uio.no/bitstream/handle/10852/61396/Linking\%2BInstruction\%2Band\% 2BStudent\%2BAchievement.pdf?sequence $=2$

Kuhn, D. (1991). The skills of argument. Cambridge University Press.

Kunnskapsdepartementet (2013). Ny GIV: Overgangsprosjektet - konsekvenser for skolen. regjeringen.no. https://www.regjeringen.no/no/dokumenter/ny-givovergangsprosjektet---konsekvense/id746690

Kunnskapsdepartementet (2016). Fag - Fordypning - Forståelse - En fornyelse av Kunnskapsløftet. (Meld. St. 28). https://www.regjeringen.no/no/dokumenter/meld.-st.-2820152016/id2483955/

Kunnskapsdepartementet (2017). Lærelyst - tidlig innsats og kvalitet i skolen. (Meld. St. 21). https://www.regjeringen.no/no/dokumenter/meld.-st.-21-20162017/id2544344/

Lefstein, A. (2008). Changing Classroom Practice Through the English National Literacy Strategy: A Micro-Interactional Perspective. American Educational Research Journal, 45(3), 701-737. https://doi.org/10.3102/0002831208316256

Lefstein, A. \& Snell, J. (2014). Better than best practice. Developing teaching and learning through dialogue. Routledge.

Lindensjö, B. \& Lundgren, U. P. (2000). Utbildningsreformer och politisk styrning. HLS Förlag 
Mehan, H. (1979). Learning lessons: Social organization in the classroom. Harvard University Press.

Matre, S. \& Fottland, H. (2011). Text, talk and thinking together: Using action research to improve third grade children's talking, reading and identity construction. Nordic Studies in Education, 31, 258-274. https://ntnuopen.ntnu.no/ntnuxmlui/bitstream/handle/11250/148745/Matre_Fottland.pdf?sequence=1

Mercer, N. (1995). The guided construction of knowledge: Talk amongst teachers and learners. Multilingual Matters.

Mercer, N. (2000). Words and minds: How we use language to think together. Routledge.

Mercer, N., Wegerif, R., \& Major, L. (Red.). (2019). The Routledge International Handbook of Research on Dialogic Education. Routledge.

Murphy, P. K., Wilkinson, I. A., Soter, A. O., Hennessey, M. N. \& Alexander, J. F. (2009). Examining the effects of classroom discussion on students' comprehension of text: A meta-analysis. Journal of Educational Psychology, 101(3), 740-764.

Møller, J., Prøitz, T. S., Aasen, P. (Red.) (2010). Kunnskapsløftet - tung bør å bære? Underveisanalyse av styringsreformen i skjæringspunktet mellom politikk, administrasjon og profesjon. NIFU STEP, Norsk institutt for studier av innovasjon, forskning og utdanning, rapport 42.

NOU 2008:18. (2008). Fagopplering for framtida. Kunnskapsdepartementet.

Nystrand, M. (1997). Opening dialogue: Understanding the dynamics of language and learning in the English classroom. Teachers College Press.

Nystrand, M. (2006). Research on the role of classroom discourse as it affects reading comprehension. Research in the Teaching of English, 40(4), 392-412.

Säljö. R. (2001). Læring i praksis. Et sosiokulturelt perspektiv. Cappelen Akademisk Forlag.

Segal, A. \& Lefstein, A. (2016). Exuberant, voiceless participation: An unintended consequence of dialogic sensibilities? International Association for Research in L1 Education. file:///C:/Users/2907168/Downloads/Segal_Lefstein_201620160329T174004\%20(9).pdf

Skaftun, A., Igland, M. A., Husebø, D., Nome, S. \& Nygard, A. O. (2017). Glimpses of dialogue: transitional practices in digitalised classrooms. Learning, Media and Technology, 43(1), 1-14. https://www.tandfonline.com/doi/full/10.1080/17439884.2017.1369106

Skaftun, A. \& Wagner, Å. K. H. (2019). Oracy in year one: a blind spot in Norwegian language and literacy education? L1-Educational Studies in Language and Literature, 19, 1-20. https://11.publication-archive.com/publication/1/1855

Skaftun, A. (2020, juli 1). Inn i Fagfornyelsen: Hva mener vi med praksis? https://blogg.forskning.no/a/1706589

Smidt. J. (2004). Sjangrer og stemmer i klasserommet. Universitetsforlaget.

Svenkerud, S., Klette, K. \& Herztberg, F. (2012). Opplæring i muntlige ferdigheter. Nordic Studies in Education, 32(1), 35-49.

Svenkerud, S. (2013). «Ikke stå som en slapp potet» - elevsynspunkter på opplæring i muntlige ferdigheter. Acta Didactica Norge, 7(1), 1-16. https://doi.org/10.5617/adno.1109

Sævi, T. \& Biesta, G. J. J. (2020). Pedagogikk, periferi og verdi. Fagbokforlaget.

Utdanningsdirektoratet. (2006). Muntlige ferdigheter. https://www.udir.no/laring-ogtrivsel/rammeverk/rammeverk-for-grunnleggende-ferdigheter/2.2-muntlige-ferdigheter/

Utdanningsdirektoratet. (2007). Gi rom for lesing! Strategi for stimulering av leselyst og leseferdighet 2003-2007. Utdanningsdirektoratet. https://www.udir.no/tall-ogforskning/finn-forskning/rapporter/Gi-rom-for-lesing-Oppsummering-av-rapporter-fraskoler-og-kommuner-for-2005-og-2006/ 
Utdanningsdirektoratet. (2012). Strategi for ungdomstrinnet - Motivasjon og mestring for bedre lering, 2013-2017. Utdanningsdirektoratet. https://www.udir.no/tall-ogforskning/finn-forskning/rapporter/ungdomstrinn-i-utvikling-uiu-2012-2017--sluttrapport/

Utdanningsdirektoratet. (2013). Læreplan i matematikk (MAT1-01). https://www.udir.no/kl06/MAT1-01/Hele/Kompetansemaal/etter-7.-arssteget

Utdanningsdirektoratet. (2015). Læreplan i KRLE (RLE1-02). https://www.udir.no/kl06/RLE1-02/Hele/Komplett_visning

Utdanningsdirektoratet. (2016). Språkløyper: Nasjonal strategi for språk, lesing og skriving. Utdanningsdirektoratet. https://www.udir.no/kvalitet-og-kompetanse/nasjonalesatsinger/lesestrategi/

Utdanningsdirektoratet. (2019). Overordnet del - verdier og prinsipper for grunnoppleringen. https://www.udir.no/lk20/overordnet-del/opplaringens-verdigrunnlag

Utdanningsdirektoratet (2019). Læreplanverket. https://www.udir.no/laring-ogtrivsel/lareplanverket/

van Leeuwen, T. (2008). Discourse and practice: new tools for critical analysis. Oxford University Press.

Vygotsky, L. S. (1986). Thought and language. A. Kozulin. (Red.). MIT Press.

Wegerif, R., Mercer, N. \& Dawes, L. (1999). From social interaction to individual reasoning: An empirical investigation of a possible socio-cultural model of cognitive development. Learning and Instruction, 9(6), 493-516. http://dx.doi.org/10.1016/S09594752(99)00013-4

Wegerif, R. (2013). Dialogic: Education for the Internet Age. Routledge.

Wegerif, R. (2016). Applying dialogic theory to illuminate the relationship between literacy education and teaching thinking in the context of the Internet age. L1 Educational Studies in Language and Literature, 16, 1-21.

Wertsch, J. V. (1991). Voices of the mind: A sociocultural approach to mediated action. Harvard University Press 


\section{Vedlegg 1:}

\section{Feltnotat fra én undervisningstime}

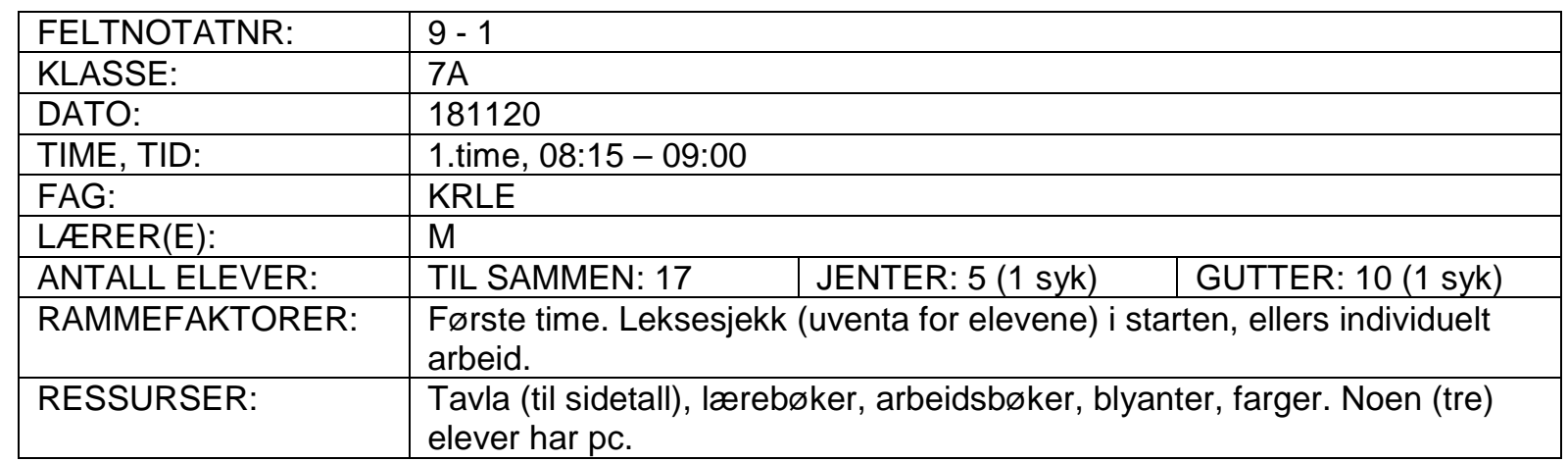

\begin{tabular}{|c|c|c|c|}
\hline HVA SKJER? & & TIDSKODE: 08:15 & \\
\hline ADMINISTRASJON & & ANNET & \\
\hline leksesjekk & & Inngang/oppstart & $x$ \\
\hline & & Utgang/avslutning & \\
\hline samle inn/dele ut & & rydding & \\
\hline Informere/gi beskjeder & & forflytning & \\
\hline HVA GJØR ELEVENE? & & $\begin{array}{l}\text { HVA GJØR } \\
\text { LÆREREN? }\end{array}$ & \\
\hline Leser & & Forteller & \\
\hline Skriver & & Instruerer & \\
\hline Snakker & & informerer & \\
\hline Lytter & & Spørsmål/svar & \\
\hline venter & & Individuell hjelp & \\
\hline ORGANISERINGSFORN & & & \\
\hline Helklasseundervisning & $x$ & $\begin{array}{l}\text { En-til-en, lærer og } \\
\text { elev }\end{array}$ & \\
\hline Gruppearbeid, lærerstyrt & & $\begin{array}{l}\text { En-til-en, elev og } \\
\text { elev }\end{array}$ & \\
\hline Gruppearbeid, elevstyrt & & Individuelt arbeid* & \\
\hline Brukt skjema med repertc & & & \\
\hline Kommentarer: & & & \\
\hline
\end{tabular}

BESKRIVELSE:

Jeg sitter på gangen og venter, og

lærer kommer 08:16 og låser opp.

Hun går ut på gangen og møter

elevene med håndhilsing og god

morgen. En elev skriver noe som ligner på plan over dagen på tavla, med «god helg» nederst. (Det blir ikke kommentert eller retta på av lærer). Lærer gir beskjed fra gangen og inn i klasserommet at elevene kan legge mobilene framme mens de venter på at alle elevene skal komme inn.

08:20 «God morgen», og alle setter seg, etter litt venting.

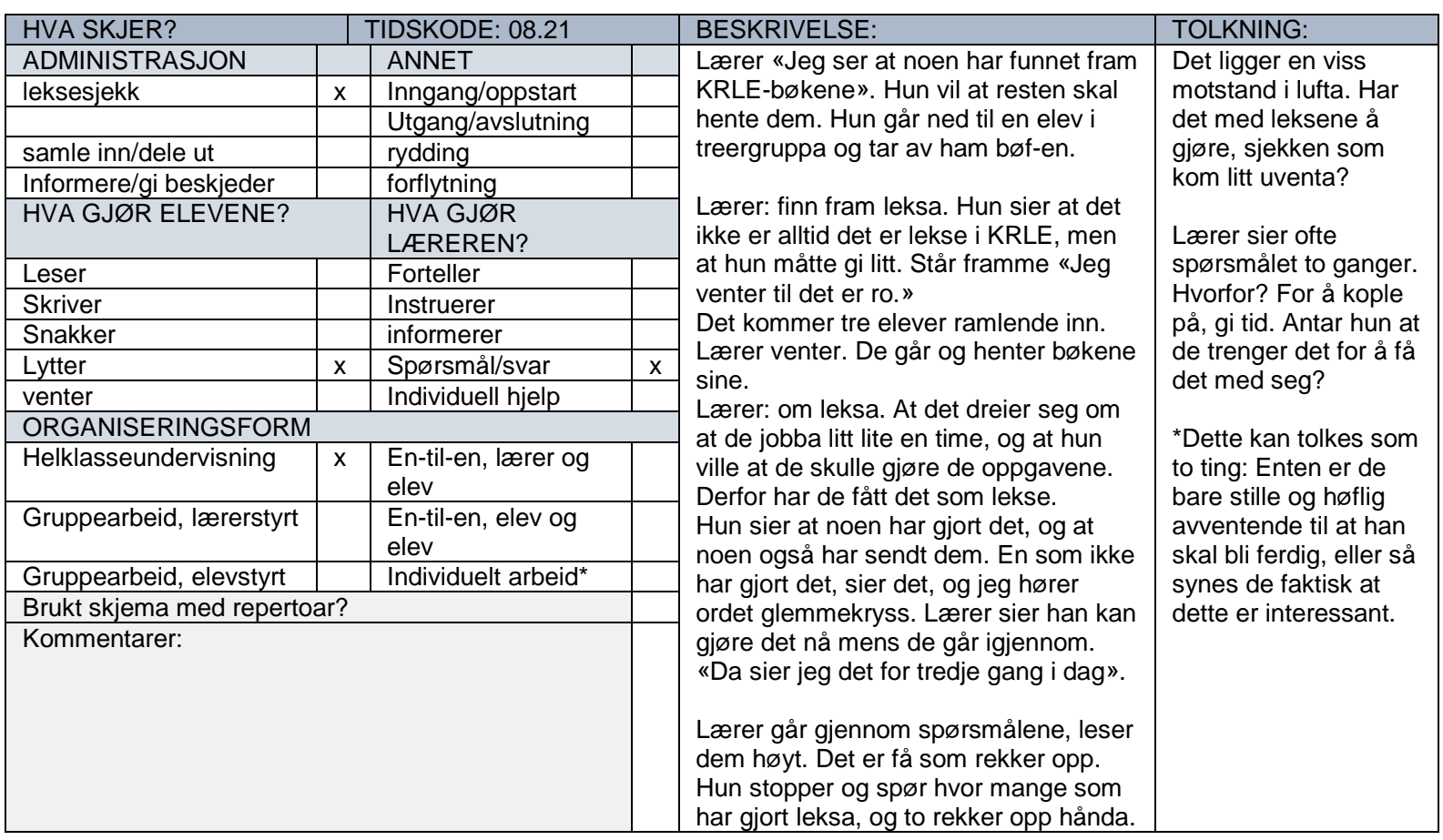




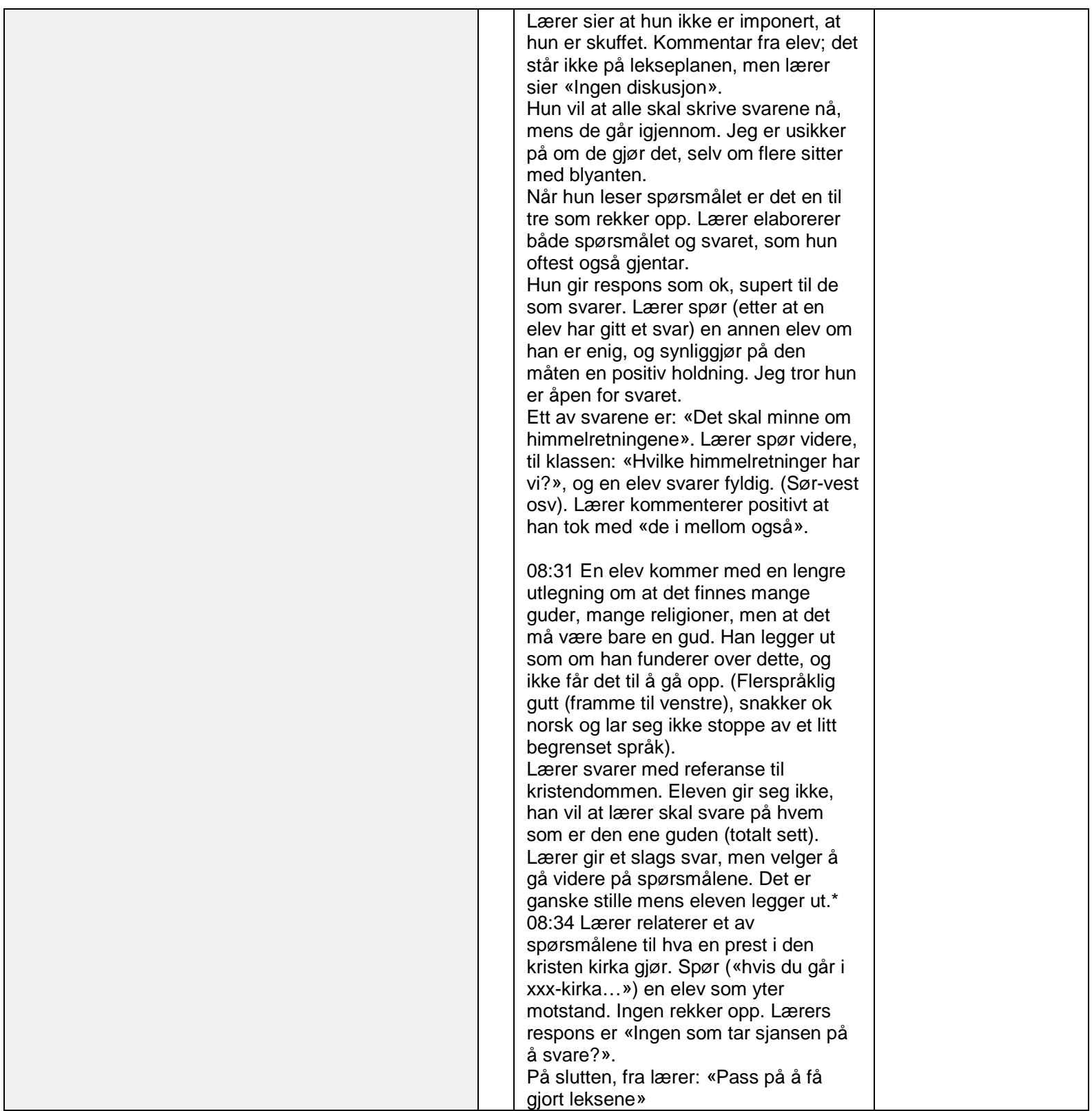

\begin{tabular}{|c|c|c|c|c|c|}
\hline \multicolumn{2}{|l|}{ HVA SKJER? } & \multirow{2}{*}{\multicolumn{2}{|c|}{ TIDSKODE: 08:35 }} & \multirow{2}{*}{$\begin{array}{l}\text { BESKRIVELSE: } \\
\text { Lærer: «Nå skal dere slå opp på side }\end{array}$} & \multirow[t]{2}{*}{ TOLKNING: } \\
\hline ADMINISTRASJON & & ANNET & & & \\
\hline \multirow[t]{2}{*}{ leksesjekk } & & Inngang/oppstart & & \multirow{16}{*}{$\begin{array}{l}262-263 \text { i boka deres.» (Skriver } \\
\text { sidetall på tavla). Lærer går fram og } \\
\text { tilbake foran tavla, med hendene på } \\
\text { ryggen, når hun instruerer klassen om } \\
\text { oppgaven. } \\
\text { Oppgaven er å lese og skrive om } \\
\text { gudene, velge en og tegne den. }\end{array}$} & \\
\hline & & Utgang/avslutning & & & \\
\hline samle inn/dele ut & & rydding & & & \\
\hline Informere/gi beskjeder & & forflytning & & & \\
\hline \multicolumn{2}{|l|}{ HVA GJØR ELEVENE? } & \multicolumn{2}{|l|}{$\begin{array}{l}\text { HVA GJØR } \\
\text { LÆEREREN? }\end{array}$} & & \\
\hline Leser & & Forteller & & & \\
\hline Skriver & & Instruerer & $x$ & & \\
\hline Snakker & & informerer & & & \\
\hline Lytter & $\mathrm{x}$ & Spørsmål/svar & & & \\
\hline venter & & Individuell hjelp & & & \\
\hline \multicolumn{4}{|l|}{ ORGANISERINGSFORM } & & \\
\hline Helklasseundervisning & $\mathrm{x}$ & $\begin{array}{l}\text { En-til-en, lærer og } \\
\text { elev }\end{array}$ & & & \\
\hline Gruppearbeid, lærerstyrt & & $\begin{array}{l}\text { En-til-en, elev og } \\
\text { elev }\end{array}$ & & & \\
\hline Gruppearbeid, elevstyrt & & Individuelt arbeid* & & & \\
\hline \multirow{2}{*}{\multicolumn{3}{|c|}{$\begin{array}{l}\text { Brukt skjema med repertoar? } \\
\text { Kommentarer: }\end{array}$}} & & & \\
\hline & & & & & \\
\hline
\end{tabular}




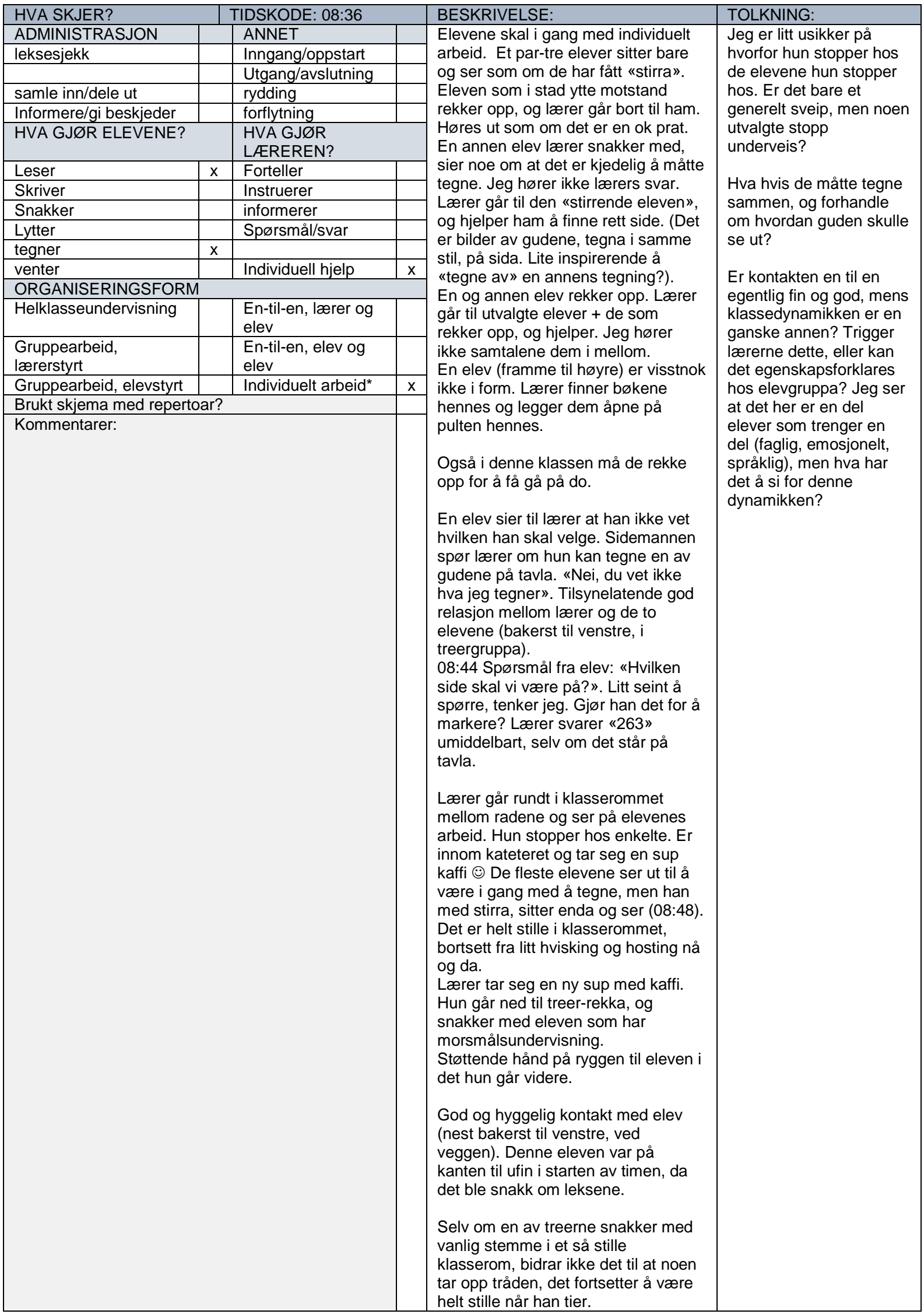

\begin{tabular}{|l|l|l|l|l|}
\hline HVA SKJER? & BESKRIVELSE: & TOLKNING: \\
\hline ADMINISTRASJON & ANNET & & $\begin{array}{l}\text { Lærer runder av med å si at det å } \\
\text { tegne en gud, og å skrive om åtte }\end{array}$ & \\
\hline leksesjekk & Inngang/oppstart & & \\
\hline
\end{tabular}




\begin{tabular}{|c|c|c|c|c|}
\hline & $\begin{array}{l}\mathrm{K} \& \mathrm{H} \\
\text { 1: Samtale om K\&H- } \\
\text { produktene elevene lager } \\
(1 \mathrm{~min})\end{array}$ & & $\begin{array}{l}\text { 46: Lærer spør hvilket bilde } \\
\text { elevene har av Columbus (3 } \\
\text { min) } \\
\text { 50: Lærerinitiert samtale om } \\
\text { det elevene har funnet ut om } \\
\text { Columbus (5 min) } \\
\text { 52: Lærer spør igjen hvilket } \\
\text { bilde de nå har av } \\
\text { Columbus, etter å ha } \\
\text { undersøkt enda mer (4 min) } \\
\text { KRLE: } \\
\text { 25: Utforsking av } \\
\text { etikkbegrepet, der lærer } \\
\text { bl.a. spør om noen har tenkt } \\
\text { på en annen måte (4 min) } \\
\text { MATEMATIKK: } \\
\text { 2: Diskusjon og komikk } \\
\text { rundt trekking av } \\
\text { julekalender (9 min) }\end{array}$ & \\
\hline Elevinitiert & $\begin{array}{l}\text { NORSK: } \\
\text { 7: Elevene forteller sine } \\
\text { avslutninger på tekstene de } \\
\text { har skrevet, og } \\
\text { kommenterer hverandres } \\
\text { (0,5 min) } \\
\text { 37: En elev kommenterer } \\
\text { gjengivelsen av detaljer på } \\
\text { film (1 min) } \\
\text { SAMFUNNSFAG: } \\
\text { 44: En elev spør om Norge } \\
\text { var koloni (0,5 min) } \\
\text { 45: Spørsmål om Columbus } \\
\text { var «mannen bak» slaveriet } \\
\text { (0,5 min) } \\
\text { 48: Spørsmål fra elev om } \\
\text { det finnes andre } \\
\text { menneskeraser enn homo } \\
\text { sapiens (0,5 min) } \\
\text { 49: Elevspørsmål om } \\
\text { eierskap til historiske } \\
\text { artefakter man finner (0,5 } \\
\text { min) } \\
\text { 51: Elever legger fram noe } \\
\text { de har funnet på Ikkepedia } \\
\text { (1 min) }\end{array}$ & $\begin{array}{l}\text { NORSK: } \\
\text { 5A: Samtale mellom lærer } \\
\text { og elev om ei lekse som } \\
\text { ikke er gjort (0,5 min) } \\
\text { 10: Spørsmål om de snart } \\
\text { skal sitte i grupper (1 min) } \\
\text { 12: Spørsmål om hvem jeg } \\
\text { (forskeren) er (1 min) } \\
\text { 29: En elevs kommentar } \\
\text { om at han kjenner den nye } \\
\text { vikaren (1 min) } \\
\text { 54: Ny runde med spørsmål } \\
\text { om spillrommet (1 min) (jf. } \\
\text { pnkt 53). } \\
\text { 56: En elev har spørsmål } \\
\text { om lydopptakeren (1 min) } \\
\text { SAMFUNNSFAG: } \\
\text { 41: En elev initierer en } \\
\text { diskusjon om Supernytt i } \\
\text { matpausen (1 min) }\end{array}$ & $\begin{array}{l}\text { NORSK: } \\
\text { 4: En elev bruker begrepet } \\
\text { selvforsvar i tolkningen av } \\
\text { Rødhette-teksten ( } 2 \text { min) } \\
\text { 18: Elev spør lærer om ei } \\
\text { bok som står framme på } \\
\text { utstilling ( } 2 \text { min) } \\
\text { 20: En elev forteller om en } \\
\text { katt, og knytter dette til det } \\
\text { faglige innholdet i timen (4 } \\
\text { min) } \\
\text { 36: Diskusjon om penger og } \\
\text { forfalsking (2 min) } \\
\text { SAMFUNNSFAG: } \\
\text { 47: En elev protesterer på at } \\
\text { noen kan ta land når det } \\
\text { allerede bor noen der (3 } \\
\text { min) } \\
\text { KRLE: } \\
\text { 8: Spørsmål om når de skal } \\
\text { se Reveenka (2 min) } \\
\text { 24: I lærers gjennomgang av } \\
\text { etikkbegrepet spør en elev } \\
\text { hva dét har med KRLE å } \\
\text { gjøre (3 min) } \\
\text { 35: En elev kommer med } \\
\text { innspill om at alle guder ikke } \\
\text { kan være Gud (3 min) }\end{array}$ & $\begin{array}{l}\text { NORSK: } \\
\text { 53: Spørsmål og samtale } \\
\text { om det nye spillrommet } \\
\text { på skolen (2 min) }\end{array}$ \\
\hline
\end{tabular}




\begin{tabular}{|l|l|l|l|l|}
\hline & $\begin{array}{l}\text { 15: Spørsmål om } \\
\text { framgangsmåte i laging av } \\
\text { papirstjerner (1 min) }\end{array}$ & $\begin{array}{l}\text { ENGELSK: } \\
\text { 16: Diskusjon rundt resultat } \\
\text { i laging av papirstjerner (1 } \\
\text { min) }\end{array}$ & $\begin{array}{l}\text { 34: Elev spør om ei lekse (1 } \\
\text { min) }\end{array}$ & \\
$\begin{array}{l}\text { 17: Elevene viser hva de } \\
\text { har fått til (1 min) }\end{array}$ & & & \\
\hline
\end{tabular}

